\title{
MicroRNA Profiles in Calcified and Healthy Aorta Differ: Therapeutic Impact of miR-145 and miR-378
}

Running title: miRNA replacement in aortic calcification

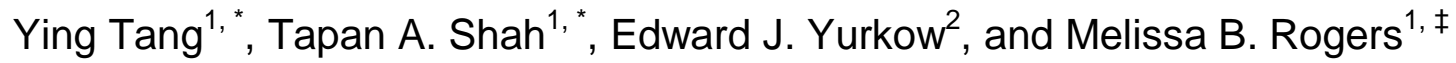

${ }^{1}$ Rutgers - New Jersey Medical School, Microbiology, Biochemistry, \& Molecular

Genetics, Newark, NJ

${ }^{2}$ Rutgers University Molecular Imaging Center (RUMIC), Rutgers University, Piscataway, NJ

"Co-first authors

¥To whom correspondence and reprint requests should be addressed: Melissa B. Rogers, Ph.D., Microbiology, Biochemistry \& Molecular Genetics, Rutgers - NJ Medical School (NJMS), Center for Cell Signaling, Room F1216, 205 South Orange Ave., Newark, NJ 07103. Email: rogersmb@njms.rutgers.edu, telephone: 9739722984

Conflict of Interest statement: The authors declare that they have no conflicts of interest with the contents of this article.

Data Availability Statement: MicroRNA microarray data has been deposited with $\mathrm{NIH} / \mathrm{NCBI}$ as GEO dataset GSE135759. The data that support the findings of this study are openly available in https://www.ncbi.nlm.nih.gov/geo/query/acc.cgi?acc=GSE135759.

Supplementary data are available on https://figshare.com/articles/supporting_docx/12550967 
miRNA replacement in aortic calcification

\begin{abstract}
Our goal was to elucidate microRNAs (miRNAs) that may repress the excess bone morphogenetic protein (BMP) signaling observed during pathological calcification in the Klotho mouse model of kidney disease. We hypothesized that restoring healthy levels of miRNAs that post-transcriptionally repress osteogenic calcific factors may decrease aortic calcification. Our relative abundance profiles of miRNAs in healthy aorta differ greatly from those in calcified mouse aorta. Many of these miRNAs are predicted to regulate proteins involved in BMP signaling and may control osteogenesis. Two differentially regulated miRNAs, miR-145 and miR-378, were selected based on three criteria: reduced levels in calcified aorta, the ability to target more than one protein in the BMP signaling pathway, and conservation of targeted sequences between humans and mice. Forced expression using a lentiviral vector demonstrated that restoring normal levels repressed the synthesis of BMP2 and other pro-osteogenic proteins and inhibited pathological aortic calcification in Klotho mice with renal insufficiency. This study identified miRNAs that may impact BMP signaling in both sexes and demonstrated the efficacy of selected miRNAs in reducing aortic calcification in vivo. Calcification of the aorta and the aortic valve resulting from abnormal osteogenesis is common in those with kidney disease, diabetes, and high cholesterol. Such vascular osteogenesis is a clinically significant feature. The calcification modulating miRNAs described here are candidates for biomarkers and "miRNA replacement therapies" in the context of chronic kidney disease and other pro-calcific conditions.
\end{abstract}

Keywords: bone morphogenetic proteins, gene regulation, signal transduction, cardiovascular system, vascular calcification, renal insufficiency, microRNA 
bioRxiv preprint doi: https://doi.org/10.1101/736330; this version posted July 29, 2020. The copyright holder for this preprint (which was not certified by peer review) is the author/funder. All rights reserved. No reuse allowed without permission.

miRNA replacement in aortic calcification

\section{Introduction}

The American Heart Association projects that $45 \%$ of Americans will have some form of heart and/or vascular disease by 2035 (5). Calcification of blood vessels reduces their diameter and plasticity and ultimately promotes ischemic events (22). Risk factors that promote both vascular and valvular calcification include aging, renal failure, and male sex; as well as hypercholesterolemia, smoking, and diabetes $(46,54)$. An aging population and the epidemic of obesity ensure that cardiovascular disorders will be a major public health threat for decades to come. Understanding the signaling processes that regulate the behavior of vascular cells will reveal novel approaches to preventing and treating these devastating pathologies. Here we focused on identifying microRNAs (miRNAs) that regulate pathological cardiovascular calcification.

The BMP signaling pathway is essential for osteogenesis and vascular calcification (8, 16, 46). BMP ligands bind BMP receptors (BMPR), which phosphorylate and activate SMAD signaling. SMAD signaling increases transcription of Runx2 and Msx2, which are master osteogenic transcription factors that promote osteogenic differentiation (16, 25, 46). Abnormally elevated levels of the pro-osteogenic bone morphogenetic protein 2 (BMP2) and increased BMP signaling are implicated in all forms of pathological cardiovascular calcification. For example, BMP2 is synthesized in human atherosclerotic plaques (7) and calcified stenotic valves (33). Moreover, BMP2 can induce the pro-osteogenic RUNX2 and MSX2 proteins in valve and aortic cells and can induce calcification and ossification both in vivo and in vitro $(7,10,30,32,34,36,37,49$, $51,53)$. Genetic deficiency and pharmacological inactivation of BMP signaling reduced calcification not only in cultured cells $(4,17,49)$ but also in several mouse models including Klotho mutant mice with renal failure $(14,17,28)$.

Given the importance of BMP signaling in cardiovascular calcification, identifying posttranscriptional regulators of BMP signaling may provide new insights and targets for the treatment of cardiovascular disease. To increase potential clinical translatability, we also considered evolutionary conservation. The 3 '-untranslated region (3'-UTR) of messenger RNAs (mRNAs) binds regulatory proteins and miRNAs that influence polyadenylation, translation efficiency, and stability of mRNAs (12). All BMP ligands may be post-transcriptionally regulated. However, the extreme evolutionary conservation of the Bmp2 3'-UTR relative to other BMP ligand 3'-UTRs supports a potentially greater role for post-transcriptional $B m p 2$ regulatory mechanisms that are conserved between mouse and man $(15,39,43)$. MicroRNAs are crucial regulators in cardiovascular pathologies (21). The goal of this study was to compare the profiles of miRNAs that modulate the synthesis of BMP2 and downstream BMP signaling proteins in the aorta of healthy mice relative to mice with pathologically calcified aorta. Our mouse model is a Klotho hypomorph that causes dysregulated mineral metabolism (24).

The phenotype of mice homozygous for Klotho mutations includes a short lifespan, atherosclerosis, ectopic calcification, and renal disease. The KLOTHO protein, along with $1,25(\mathrm{OH})_{2}$ vitamin D3 and FGF23, tightly regulates phosphate homeostasis (19, 50). Deficiency of KLOTHO leads to renal disease and subsequent hyperphosphatemia and ectopic calcification of soft tissues such as aorta, aortic valves and kidneys (17, 50). Restoration of normal KLOTHO levels ameliorates calcification (19). The dramatic calcification of the aorta and other tissues in Klotho mutant mice within 6-7 weeks of 
bioRxiv preprint doi: https://doi.org/10.1101/736330; this version posted July 29, 2020. The copyright holder for this preprint (which was not certified by peer review) is the author/funder. All rights reserved. No reuse allowed without permission.

miRNA replacement in aortic calcification

birth make them experimentally attractive for studying gene regulation and signaling changes during pathological calcification. Understanding the mechanism of aortic calcification in the context of kidney failure is important because $17 \%$ of the population over the age of 30 may suffer from this major cardiovascular disease risk factor by 2030 (5).

Our objective was to elucidate a comprehensive profile of miRNAs whose abundance is altered in the calcified aorta of Klotho homozygous mutant mice with renal disease. Our miRNA profiles from both male and female healthy and diseased mice reflect the extensive changes that occur during vascular disease. Here we discuss the subset of differentially regulated miRNAs that may impact the pathological osteogenesis that contributes to vascular calcification. We also demonstrate that selected miRNAs can modulate the BMP2 ligand and proteins involved in BMP signaling and calcification in vivo. Finally, we provide proof-of-principle evidence that increasing the abundance of miRNAs that inhibit BMP signaling can ameliorate aortic calcification. This study begins to fill a key gap in our understanding of post-transcriptional processes that control BMP signaling and calcification in vascular tissues and provides experimental support for miRNA replacement therapies in cardiovascular disease.

\section{Material and Methods}

\section{Tissue collection}

Mice bearing the Klotho mutation were a gracious gift from Dr. Makoto Kuro-o (Jichi Medical University) by way of Dr. Sylvia Christakos (Rutgers New Jersey Medical School). The mice were a mixture of strains FVB, C57BI/6J, and C3H/J. Because homozygous Klotho null mice are infertile, mice were maintained by heterozygous-byheterozygous mating. $25 \%$ of each litter was homozygous and exhibited the full Klotho phenotype, including ectopic soft tissue calcification. $50 \%$ were heterozygous and $25 \%$ were wild type. No statistically significant differences in any parameter were observed between mice bearing the heterozygous and wild type Klotho genotypes (Table S1). Assessed parameters included body and organ weights, gene expression, and calcium levels. Because our analyses were consistent with published data indicating that the Klotho mutation is fully recessive, heterozygous and wild type samples were presented together as "healthy control" samples. In all experiments, tissues from both male and female mice were assayed. The resulting data were presented with closed and open circles indicating male and female values, respectively.

All animal procedures were in accordance with the guidelines for Care and Use of Experimental Animals and approved by the NJ Medical School Institutional Animal Care and Use Committee (IACUC protocol \#PROTO999900898). Control and Klotho homozygote mice were fed regular chow and euthanized at $50 \pm 1$ days of age. After weaning, Klotho homozygotes received softened chow on the floor of the cage. On the day of necropsy, mice were killed with an inhalation overdose of isoflurane. Immediately thereafter, the heart was perfused via the left ventricle with phosphate buffered saline (PBS, pH 7.3), to remove excess blood. The aorta, including the ascending aorta, arch and descending thoracic aorta, was removed. After cutting at the surface of the heart, the aorta was rinsed in PBS, blot dried and weighed. The aorta 
bioRxiv preprint doi: https://doi.org/10.1101/736330; this version posted July 29, 2020. The copyright holder for this preprint (which was not certified by peer review) is the author/funder. All rights reserved. No reuse allowed without permission.

miRNA replacement in aortic calcification

was snap-frozen in liquid nitrogen and stored at $-80^{\circ} \mathrm{C}$. Frozen tissues were ground in liquid nitrogen using a mortar and pestle. To facilitate handling small tissues such as the diseased aortas from Klotho homozygotes, acid-washed glass beads (Millipore-SIGMA, St. Louis, MO, \# G1277) were added during the grinding to both mutant and control tissues. Glass beads did not affect the biochemical assays (Fig. S1A, B).

\section{Western Blots}

Frozen ground tissue was solubilized in RIPA buffer, sonicated, and subjected to western blot analyses as described in Shah et al. (43). BMP signaling was measured using a monoclonal phospho-SMAD 1/5/9(8) antibody (Cell Signaling Technology, Danvers, MA, \#13820) at a dilution of 1:1000. The PSMAD antibody was authenticated as described in Fig. S1C and D. Polyclonal total SMAD 1/5/9(8) (Santa Cruz Biotechnology, Inc., Santa Cruz, CA, \#sc-6031-R) and a polyclonal actin antibody (Santa Cruz Biotechnology, Inc., Santa Cruz, CA, \#sc-1615-R) were used at a dilution of 1:1000. Both PSMAD and tSMAD antibodies recognize the three BMP specific SMADs 1, 5, 9. In all cases, the secondary antibody was Goat Anti-Rabbit HRP (Abcam, Cambridge, MA, \# ab97080) at a dilution of 1:20,000. Antibody-bound proteins were detected using SuperSignal ${ }^{\mathrm{TM}}$ West Femto Maximum Sensitivity Substrate (ThermoFisher Scientific, Waltham, MA, \# 34096) and imaged using a FluoroChem M (Protein Simple, San Jose, California).

\section{Calcium assays}

Ground tissue was solubilized and lysed by sonication on ice in PBS, pH 7.3 containing $0.16 \mathrm{mg} / \mathrm{mL}$ heparin. The Cayman Chemical Calcium Assay kit was used to measure calcium levels (Ann-Arbor, MI, \#701220). Calcium levels were normalized to protein levels measured using the Bradford assay (Bio-Rad Laboratories, Hercules, CA, \# 5000006).

\section{Spatial mapping of calcified structures}

The patterns of mineralization in Klotho heterozygote vs. Klotho mutant mice were determined using microcomputerized tomography (microCT) at the Rutgers Molecular Imaging Center (http://imaging.rutgers.edu/). Mice were scanned using the Albira $\AA$ $\mathrm{PET} / \mathrm{CT}$ (Carestream, Rochester, NY) at standard voltage and current settings (45kV and $400 \mu \mathrm{A}$ ) with a minimal voxel size of $<35 \mu \mathrm{m}$. Voxel intensities in the reconstructed images were evaluated and segmented with VivoQuant image analysis software (version 1.23, inviCRO LLC, Boston).

\section{MicroRNA microarray and data analysis}

Aortic samples were obtained from both male and female control and Klotho mutant mice at 7 to 8 weeks of age (Table 1). RNA was extracted using the miRNeasy Mini Kit (Qiagen Inc., Germantown, MD, \# 217004). The RNA quality was checked using a Bioanalyzer (Agilent Technologies, Santa Clara, CA).

MicroRNA expression in the aorta was assessed with the Applied Biosystems ${ }^{\mathrm{TM}}$ GeneChip TM miRNA 4.0 Array (ThermoFisher Scientific, Waltham, MA, \#902412) in the Rutgers NJMS Genomics Center. The GeneChip ${ }^{\mathrm{TM}}$ miRNA 4.0 Array contained the miRNAs and pre-miRNAs (precursors to the miRNAs) listed in the Sanger miRBase v20. The miRNA arrays were processed following the manufacturer's instructions. 
bioRxiv preprint doi: https://doi.org/10.1101/736330; this version posted July 29, 2020. The copyright holder for this preprint (which was not certified by peer review) is the author/funder. All rights reserved. No reuse allowed without permission.

miRNA replacement in aortic calcification

Briefly, using the Applied Biosystems ${ }^{\mathrm{TM}}$ FlashTag TM Biotin HSR RNA Labeling Kit (ThermoFisher Scientific, Waltham, MA, the \# 902446), $400 \mathrm{ng}$ of total RNA was labeled with biotin and hybridized to the miRNA 4.0 Array (ThermoFisher Scientific, Waltham, $\mathrm{MA}, \# 902412$ ) for 18 hours at $48^{\circ} \mathrm{C}$ using an Affymetrix $\AA^{8} 450$ Hybridization Oven (Affymetrix, Santa Clara, CA). After washing and staining on an Affymetrix® 450 Fluidics Station (Affymetrix, Santa Clara, CA), using the Applied Biosystems ${ }^{\mathrm{TM}}$ GeneChip ${ }^{\text {TM }}$ Hybridization, Wash, and Stain Kit (ThermoFisher Scientific, Waltham, MA, \#900720), the arrays were scanned using the Affymetrix ${ }^{\circledR}$ Scanner $30007 G$ (Affymetrix, Santa Clara, CA). CEL files were generated using the Affymetrix data extraction protocol in the Affymetrix GeneChip $\AA^{\circledR}$ Command Console ${ }^{\circledR}$ Software (Affymetrix, Santa Clara, CA, USA). The resulting CEL files (GSE135759) were analyzed using the Partek Genomics Suite 7.0 (Partek Inc., St. Louis, MO), including the Robust-Multi-array Average algorithm to correct for microarray background and to normalize miRNA expression profiles on a log scale. Partek Genomic's ANOVA analysis identified the miRNAs whose abundance differed significantly between control and Klotho homozygous mutant mice. Minimal significance was defined as a $p$ value of 0.05 .

\section{Bioinformatic analyses}

MicroRNAs that were significantly down-regulated in both sexes of Klotho homozygous mice compared to controls were (further) used to perform target prediction (see microarray data analysis). Predicted target profiles were obtained from the DNA Intelligent Analysis (DIANA)-micro T-CDS (v. 5.0) which permits the entry of multiple miRNAs simultaneously (http://www.microrna.gr/webServer) (38). The micro T-CDS threshold score for predicted targets was set at 0.6. Scores ranged from 0 to 1 , with a higher score indicating an increased probability of a true microRNA target.

Alignments between selected miRNAs and mouse genes were predicted by MiRanda (6) and TargetScan 7.2 (http://www.targetscan.org/mmu 72/ (1)).

\section{Real-Time Reverse Transcription PCR for detection of microRNA-145 and microRNA-378a and target gene expression}

MicroRNA cDNA was synthesized using the miScript PCR Kit (Qiagen Inc., Germantown, MD, \# 218073). The miScript PCR kit utilized a universal oligo-dT primer tag to convert all RNA species (total RNA and miRNA) into cDNA. A universal reverse primer supplied with the miScript PCR kit was used to amplify cDNA from each miRNA. The miRNA forward primers were designed based on miRNA sequences in miRBase 22 (http://www.mirbase.org/). GCG or CGC was added to the 5' end of the primers when the GC \% was low. NCBI nucleotide blast was used to confirm the absence of nonspecific binding sites for the forward primers. Messenger RNA (mRNA) cDNA was synthesized using the QuantiTect ${ }^{\circledR}$ Reverse Transcription kit (Qiagen Inc., Germantown, MD, \# 205313). Intron-spanning primers for mRNA were used to eliminate amplicons generated from any contaminating genomic DNA. Primer sequences are shown in Table 2.

Quantitative PCR was performed on a CFX96 Touch $^{\text {TM }}$ Real-Time PCR Detection System (Bio-Rad Laboratories, Hercules, CA, \#1855196) using the QuantiTect@ SYBR $\circledast$ Green PCR kit (Qiagen Inc., Germantown, MD, \#204145) under the following conditions: $15 \mathrm{~min}$ at $95^{\circ} \mathrm{C}, 39$ cycles of 15 seconds at $94^{\circ} \mathrm{C}, 30$ seconds at $55^{\circ} \mathrm{C}$ and 
30 seconds $70^{\circ} \mathrm{C}$. MicroRNA abundance was normalized to U6 and mRNA expression was normalized to actin. The human U6 primer used in this experiment was included in the miScript Primer assay kit (Qiagen Inc., Germantown, MD, \#218300).

\section{Lentivirus generation and titering performed by Biosettia, Inc. (San Diego, CA).}

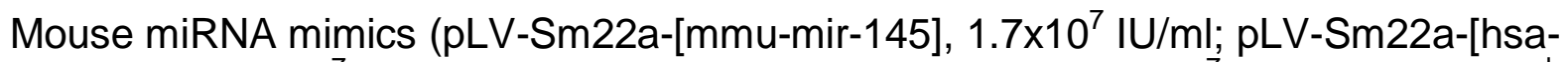
mir-378a], $2.1 \times 10^{7} \mathrm{IU} / \mathrm{ml}$ ) or control (pLV-Sm22a-[mir-ctrl], $1.7 \times 10^{7} \mathrm{IU} / \mathrm{ml}$ ) bearing $3^{\text {rd }}$ generation vectors (Vesicular Stomatitis Virus (VSV) G pseudotype) were purchased from Biosettia, Inc. The mature mir-378a sequences generated from the human precursor are identical to the mouse mature sequences. General information regarding Biosettia self-inactivated lentiviral vectors can be found at $h$ ttps://biosettia.com/mirna/. Briefly, the miRNA precursors were cloned within the intron of the human EF1a promoter region in which the EF1a promotor was replaced by the mSm22a promoter. The pLV-microRNA vectors were cotransfected with three helper plasmids (Gag-pol, Rev and VSV-G) and measured using the antibiotics selection method (blasticidin). Synthesis and titering are described at https://biosettia.com/download/protocols/biosettia-mirna-lentiviral-expression-vectormanual.pdf.

\section{Lentiviral microRNA-145 and microRNA-378a transduction}

Lentivirus vectors expressed the mir-145 or mir-378a precursor RNAs under the control of the vascular smooth muscle cell (VSMC)-specific mSm22a promoter. This wellcharacterized minimal promoter directs gene expression specifically in VSMCs of large and medium-sized arteries in adult mice, with no expression in other muscle cells or organs including the kidney and liver $(11,26,27,31)$. The negative control was the empty virus vector. Newly weaned Klotho mutant homozygotes were injected with empty lentivirus or lentivirus bearing mir-145 or mir-378a via their tail veins on 5 alternate days. The total lentivirus achieved in each mouse at the end of the treatment window was $4 \times 10^{5} \mathrm{IU} / \mathrm{g}$ body weight. The mir- 145 lentivirus generates two mature miRNAs: miR-145a-5p and miR-145a-3p. The mir-378a lentivirus generates two mature miRNAs: miR-378a-5p and miR-378a-3p.

\section{Statistical Analysis}

Data were analyzed with GraphPad (version 7; GraphPad Software Inc, La Jolla, CA) and are presented as mean \pm Standard Error Measurement (SEM) as indicated. Statistical significance was assessed with the Student's two-tailed t-test. Differences were considered significant if $p<0.05$. The significance of any differences in male and female values was assessed by a t-test. With one exception, the male and female RTPCR, western blot, and calcium values did not significantly differ. Consequently, male and female values are indicated as closed or open circles and were pooled for statistical calculations. The one exception, miR-378a-3p levels, are noted in the results and figure legends.

\section{Results}


bioRxiv preprint doi: https://doi.org/10.1101/736330; this version posted July 29, 2020. The copyright holder for this preprint (which was not certified by peer review) is the author/funder. All rights reserved. No reuse allowed without permission.

miRNA replacement in aortic calcification

\section{BMP signaling and calcification is elevated in aorta from Klotho homozygous mutant mice}

BMP signaling is required for valve calcification in Klotho null mice (17). We assessed BMP signaling in the calcified aorta of mice homozygous for the original hypomorphic Klotho allele (24). BMP signaling and calcium levels in aorta from control mice that were either wild type $\left(\mathrm{K}^{+/+}\right)$or heterozygous $\left(\mathrm{K}^{k / /+}\right)$ for the Klotho mutation were compared to the aorta from Klotho mutant homozygotes $\left(K l^{k / k k}\right)$. BMP signaling, as assessed by phosphorylation of the three BMP-specific SMADs 1, 5, and 9, was induced nearly 2 -fold in aorta from male and female Klotho homozygous mice relative to control mice (Fig. 1A, B; $p=0.002$ ). Calcium levels in the aorta from Klotho mutant homozygotes also were elevated by over 2 -fold relative to control aorta (Fig. 1C, $\mathrm{p}<0.0001)$. PET-CT imaging revealed profound mineralization in the aortic sinus and ascending aorta of Klotho mutant $\left(\left.K\right|^{k / k)}\right)$ mice, but not in a control heterozygous $\left(K^{k / /+}\right)$ littermate (Fig. 1D, E). Together, these results confirmed that homozygosity for the hypomorphic Klotho mutation amplifies BMP signaling and calcification in the aorta.

We then tested the hypothesis that increased abundances of aortic RNAs encoding the ligand BMP2 or the BMP signaling intermediaries SMADs 1, 5, or 9 accounted for the increased signaling in the Klotho homozygotes. The levels of the Bmp2 and Smad1 RNAs were similar to those in control mice (Fig. 1F, G). In contrast, Smad5 and 9 RNA levels were 1.4-fold and 3.0-fold higher, respectively, in the aorta of Klotho homozygotes compared to control mice (Fig. $1 \mathrm{H}, \mathrm{I}, \mathrm{p}<0.05$ and $\mathrm{p}<0.01$ ). Although we have yet to rule out differential translation of the Bmp2 and Smad1 RNAs, we did not observe disease-associated differences in mRNA abundances. However, the increased abundance of the RNAs encoding the SMAD5 and 9 intracellular BMP signaling intermediaries indicates that increased transcription and/or stability of messages that encode BMP signaling proteins occurs in the aorta of Klotho mutant homozygotes.

\section{MicroRNA profiles differ in the aorta from Klotho homozygous mutant mice}

BMP signaling and calcium levels are doubled in the aorta of Klotho homozygotes (Fig.

1). Alterations in miRNAs that target pro-calcific ligands such as BMP2 or signal intermediaries such as the SMADs may alter translational efficiency or destabilize mRNAs leading to changes in abundance. Consequently, we hypothesized that miRNA profiles differ in aorta from healthy control mice and Klotho homozygous mutant mice with dysregulated mineral metabolism. To identify miRNAs involved in aortic calcification, we profiled miRNAs in aortas from control healthy and Klotho mutant homozygotes. In total, 145 miRNAs were significantly increased, and 106 miRNAs were significantly decreased in Klotho mutant homozygous males relative to control mice ( $p<0.05$, Fig. 2A, Table 3, Table S2, GSE135759). In Klotho mutant females, 121 miRNAs were significantly increased, and 92 miRNAs were significantly decreased ( $p<0.05$, Fig. 2B, Table 3, Table S2, GSE135759). The abundances of 31 miRNAs were altered significantly in both male and female Klotho homozygous mutant mice relative to control mice ( $<<0.05$, Fig. $2 \mathrm{C}$, Table 4$)$. Of these 10 miRNAs were upregulated and 12 miRNAs were down-regulated in both sexes of Klotho homozygous mice. These results are consistent with a major role for miRNA-mediated posttranscriptional regulation in aortic calcification. 
bioRxiv preprint doi: https://doi.org/10.1101/736330; this version posted July 29, 2020. The copyright holder for this preprint (which was not certified by peer review) is the author/funder. All rights reserved. No reuse allowed without permission.

miRNA replacement in aortic calcification

Curiously, the abundances of 9 miRNAs were altered by Klotho homozygosity but in the opposite directions in each sex: miR-3069-3p, miR-7019-5p, miR-7685-3p, miR-679-5p and miR-370-5p were up-regulated in males and down-regulated in females, whereas miR-7665-3p, miR-466m-3p, miR-17-5p and miR-181c-3p were down-regulated in males and up-regulated in females (Table 4). The focus of this study was to restore natural repressive mechanisms whose weakening may contribute to pathological calcification. Therefore, we focused on miRNAs whose abundance is reduced in the calcified aorta of both sexes.

A manually compiled list of BMP signaling-relevant genes predicted by TargetScan to be targeted by selected miRNAs is shown in Table 5 . Together, these results suggest the disease-associated miRNA profile in Klotho homozygotes may influence the tendency of aortic cells to undergo osteogenic differentiation. We postulate that microRNAs that target more than one member of the BMP signaling pathway may inhibit BMP signaling by coordinately down-regulating multiple proteins and effectively restrain pathological calcification.

\section{MicroRNA-145 and microRNA-378a attenuation in Klotho mutant mice}

We selected two microRNAs to test the principle that a miRNA targeting several members of the BMP signaling pathway would reduce KLOTHO deficiency-associated calcification. Two miRNAs were selected whose abundance was reduced in Klotho mutants. To increase the potential for translational studies, each was predicted to target sequences within the transcripts encoding BMP2 and SMAD proteins that are conserved between mice and humans (Table 6).

The abundance of miR-378a-5p, was sharply decreased in both male and female Klotho mutant mice (53\% and 38\% respectively, Table 4, Table S2). RT-PCR validated our microarray results and confirmed that the abundance of miR-378a-5p and $-3 p$ in Klotho mutant mice was half that present in healthy control aorta (Fig. 3C, D). TargetScan predicted that miR-378a-5p may target 13 proteins involved in BMP signaling including Bmp2 and Smad5 (Table 5). In contrast, TargetScan failed predict that miR-378a-3p would impact BMP signaling (Table 5). Although the abundance of miR-378a-5p did not differ significantly in males and females, a significant difference in miR-378a-3p levels was observed (Fig. 3D). In this report, we focus on miRNAs that may regulate pathological osteogenesis in the Klotho model. Because miR-378a-3p is not predicted to strongly interact with BMP signaling genes, we will address this observation in a separate ongoing study of how sex impacts miRNA levels.

Our microarray measurements showed that the abundance of miR-145a-5p was reduced by $20 \%$ in male Klotho homozygous mutant mice as compared to healthy control males (Table S2). RT-PCR indicated that levels of both miR-145a-5p and $-3 p$ were significantly reduced in Klotho mutant mice of both sexes (Fig. 3A, B). We selected this miRNA for further assessment because, miR-145a is predicted to target Bmp2, Smad1, 5 and 9 (Table 5, 6, (47)), was also down-regulated in ApoE null female mice with partial nephrectomy (45), and improves atherosclerotic symptoms in a mouse model of hyperlipidemia (27). The experiments described below test the impact of restoring miR-145 abundance in an alternative setting of kidney failure with accelerated aging. 
bioRxiv preprint doi: https://doi.org/10.1101/736330; this version posted July 29, 2020. The copyright holder for this preprint (which was not certified by peer review) is the author/funder. All rights reserved. No reuse allowed without permission.

miRNA replacement in aortic calcification

\section{Forced overexpression of mir-145 and mir-378a in Klotho mutant mice}

We used a vascular smooth muscle cell (VSMC)-specific mSm22a promoter-driven lentivirus to increase the abundance of miR-145 and miR-378a in the aortas of Klotho mutant homozygotes (Fig. 4A, (27)). To evaluate the efficacies and persistence of lentiviral transduction, RT-PCR was used to test the aortic levels of miR-145 and miR$378 \mathrm{a}$ in mice injected with viruses bearing these miRNAs relative to empty virus vectors. The miR-145 virus raised miR-145a-5p and miR-145a-3p abundances by $1.4 \pm 0.8$ and $2.0 \pm 0.01$ fold, respectively, relative to empty virus (Fig. 4B, C). Similarly, miR-378a-5p abundance increased by $1.7 \pm 0.04$ fold (Fig. 4D). Although unlikely to directly influence BMP signaling, the fact that miR-378a-3p abundance increased significantly in both males and females (Fig. 4E, F) further verifies that overexpression of the precursor RNA occurred in the aorta. Thus this delivery dosage and method successfully augmented aortic miR-145 and miR-378a levels in Klotho mutant mice.

\section{Increased expression of miR-145 and miR-378a reduced BMP signaling and aortic calcification}

Four different proteins involved in BMP signaling: Bmp2, Smad1, 5 and 9 are predicted to be targeted by miR-145 (Table 5,6$)$. Therefore, we hypothesized that increased miR145 levels would repress the synthesis of these pro-osteogenesis factors and ameliorate pathological calcification. Having successfully augmented the level of miR145 with lentivirus delivery (Fig. 4), we evaluated the impact of this treatment on Bmp2 and Smad1, 5 and 9 RNA levels with RT-PCR. The Bmp2 and Smad5 RNA levels in aortas from mice injected with miR-145-bearing virus fell to $48 \pm 0.03 \%$ and $65 \pm 0.006 \%$ $(\mathrm{p}=0.002$ and 0.048 ) that of control aortas from mice injected with empty virus (Fig. 5A, C). The miR-145 virus did not significantly change the abundances of the Smad1 (Fig. 5B) and Smad9 (Fig. 5D).

To test if miR-145 overexpression inhibited pathological calcification in Klotho homozygous mutant mice, we compared the calcium present in the aortas of Klotho homozygous mutant mice injected with empty lentivirus vector or with virus bearing miR-145. The Klotho homozygous mutant mice injected with the miR-145 virus had one third less aortic calcium than the empty virus injected mice $(67 \pm 0.8 \%, p=0.02$, Fig. $5 E)$. Thus, forced miR-145 expression limited pathological calcification in Klotho aorta.

The down-regulated miR-378a-5p miRNA is predicted to target Bmp2 and Smad5, but not Smad1 and 9 (Table 5, 6). Furthermore, published reporter gene studies confirmed that miR-378 directly regulates $B m p 2(18,52)$. The circulating level of miR-378 is reduced in the plasma of patients with coronary heart disease (5) which is consistent with a role in cardiovascular calcification. To evaluate the potiential benefit of restoring miR-378a expression in the aorta of Klotho mutant mice, a lentivirus bearing miR-378a was injected. This virus reduced the levels of the target gene RNAs Bmp2 and Smad5 to $60 \pm 0.02 \%(p=0.02)$ and $64 \pm 0.4 \%(p=0.04)$ respectively of the RNA levels observed in the mice injected with empty virus (Fig. 6A and B). Finally, treatment with the mir$378 a$-bearing virus reduced aortic calcium levels by a third $(63 \pm 0.6 \%, p=0.02)$ relative to levels in mice exposed to the empty virus (Fig. 6C). Thus as observed for miR-145, forced expression of miR-378a significantly ameliorated pathological calcification of the aorta. 
bioRxiv preprint doi: https://doi.org/10.1101/736330; this version posted July 29, 2020. The copyright holder for this preprint (which was not certified by peer review) is the author/funder. All rights reserved. No reuse allowed without permission.

miRNA replacement in aortic calcification

\section{Discussion}

Large datasets comparing organs with different clinically relevant physiologies are important starting points for empirical investigations. Here, we provide comprehensive profiles of differentially regulated miRNAs in healthy $v s$. calcified aorta. Our goal is to improve our understanding of regulatory differences leading to vascular calcification. We contribute miRNA profiles in aortas from control healthy mice and in Klotho homozygous mutant mice with renal disease to the public databases. KLOTHO deficiency leads to renal impairment and pathological osteogenesis within the vasculature. This vascular bone formation involves pathologically increased BMP signaling. Consequently, we initially focused on the subset of differentially regulated miRNAs that impact BMP signaling and key osteogenesis regulators. Most importantly, we demonstrated that selected miRNAs can modulate the BMP2 ligand and proteins involved in BMP signaling and calcification in vivo. An additional strength of our study is the rigorous inclusion of samples from both male and female mice in all experiments.

The abundances of many miRNAs were changed in the same direction in both male and female mice (Table 4). However, the statistical significance of the change for some miRNAs failed to reach our cutoff of $p<0.05$ in both sexes. Consequently, only a small fraction of miRNAs whose levels changed to a statistically significant level were regulated similarly in both male and female mice (Fig. $2 \mathrm{C}$ ). This quantitative difference is partly explained by a limitation of our study whereby fewer female Klotho homozygotes were available (Table 1).

However, we also observed qualitative differences in the miRNA profiles of males and females. For example, the abundances of miR-3069-3p, miR-7019-5p, miR-7685-3p, miR-679-5p, miR-370-5p, miR-7665-3p, miR-466m-3p, miR-17-5p and miR-181c-3p changed in opposite directions in males and females (Table 4). Interestingly, a class of miRNAs that modulate epithelial mesenchymal transition (40) were highly up-regulated exclusively in the aorta of female mice. MiR-205-5p and $-3 p$ and five members of the miR-200 family (miR-141-5p and -3p, miR-200a-5p and -3p, miR-429-3p) were upregulated by as much as 65 -fold in Klotho mutant females but were unchanged in males (Table S2). Epithelial mesenchymal transition influences vascular calcification $(9,41)$. Both quantitative and qualitative differences in aortic miRNA profiles in each sex may be highly clinically relevant because there are significant disparities in incidence, prognosis, and response to treatments for arterial diseases between men and women (13). We are separately investigating the sex-associated differences in the context of a study aimed at clarifying the impact of sex on BMP signaling (42).

We selected two miRNAs, miR-145 and miR-378, to test the principle that miRNAs targeting members of the BMP signaling pathway would reduce aortic calcification. We used the Klotho hypomorphic model because the swift pace of aortic calcification in the Klotho mutant homozygotes facilitates testing therapeutic approaches to reducing calcification. In contrast, other models are experimentally time-consuming. For example, mice with genetically sensitized hyperlipidemia backgrounds must be fed special diets for months $(29,35)$. In Klotho mutant mice with hyperphosphatemia, elevated aortic BMP signaling and calcification is observed at 6-7 weeks of age (Fig. 1, 
(17)). In this model, only 10 days of exposure to viruses overexpressing miR-145 and miR-378 limited aortic calcification (Fig. 5, 6). Studies using Klotho mice with renal disease also are relevant to human biology, because KLOTHO deficiency is associated with chronic kidney disease that promotes valve and vascular calcification in people $(2$, $3,20,23)$. This work underscores the great potential for miRNA-based therapies in treating calcification pathologies.

Restoration of aortic miR-145 levels has also been tested in a different model of vascular calcification. Forced expression of miR-145 reduced atherosclerotic plaque size, increased plaque stability, and promoted a contractile cell phenotype in the $A p o E$, high fat diet mouse model of hyperlipidemia (27). Our demonstration of reduced calcification in Klotho mutant homozygous mice with forced miR-145 (Fig. 5) indicates that miR-145 also attenuates vascular disease in a model of atherosclerosis caused by hyperphosphatemia. The effectiveness of this microRNA in these highly dissimilar physiological situations suggest that miR-145 directly promotes vascular health and inhibits pathological osteogenesis.

Like miR-145, miR-378a was significantly down-regulated in blood samples from patients with coronary artery disease compared to healthy subjects (48). Furthermore, both miRNAs target regions of the BMP2 and other BMP signaling genes that are highly conserved between mice and humans (Table 6, $(18,52)$ ). Interestingly, both miRNAs are subject to editing whereby specific adenosines are post-transcriptionally converted to inosine $(44,55)$. Inosine base pairs cytosine, not thymine. Manual sequence inspection indicates that editing would increase the complementarity of miR-145 and miR-378a for sites within both the mouse and human BMP2 messages. Although editing may significantly change miRNA/message interactions, current databases and prediction tools do not facilitate global predictions of how edited miRNAs may impact signaling pathways.

In summary, we have provided a database of the miRNAs that are differentially expressed in healthy mouse aorta relative to aorta calcified due to defective mineral metabolism and kidney function. These databases and all experiments described in this report include samples from both male and female mice. We also demonstrated that forced expression of miR-145 and miR-378 inhibited RNAs encoding BMP signaling proteins and chronic kidney disease-associated aortic calcification. MiRNA-145 and miR-378 are candidates for translational studies investigating therapies to block vascular calcification. 
Acknowledgements: We warmly thank Youhua Zhu for her diligent technical assistance, Dr. Diane Garsetti and Yue Wang for critically reading the manuscript, and Lindsey Hernandez for bioinformatics assistance. We appreciate the technical assistance provided by the NJMS Genomics Center.

Tapan A. Shah's present address is Advanced Cell Diagnostics, 7707 Gateway Blvd \#200, Newark, CA 94560

Funding was provided by grants from the National Heart, Lung, and Blood Institute (R01HL114751) and National Institutes of Aging (R56AG050762) and from the NJMS Research Core Facilities Matching Funds Small Grants Program to MBR and an American Heart Association fellowship (20POST35210235) to YT. 
miRNA replacement in aortic calcification

\section{References}

1. Agarwal V, Bell GW, Nam JW, and Bartel DP. Predicting effective microRNA target sites in mammalian mRNAs. Elife 4: 2015.

2. Arking DE, Atzmon G, Arking A, Barzilai N, and Dietz HC. Association between a functional variant of the KLOTHO gene and high-density lipoprotein cholesterol, blood pressure, stroke, and longevity. Circ Res 96: 412-418, 2005.

3. Arking DE, Becker DM, Yanek LR, Fallin D, Judge DP, Moy TF, Becker LC, and Dietz HC. KLOTHO allele status and the risk of early-onset occult coronary artery disease. Am J Hum Genet 72: 1154-1161, 2003.

4. Balachandran K, Sucosky P, Jo H, and Yoganathan AP. Elevated cyclic stretch induces aortic valve calcification in a bone morphogenic protein-dependent manner. Am J Pathol 177: 49-57, 2010.

5. Benjamin EJ, Muntner P, Alonso A, Bittencourt MS, Callaway CW, Carson AP, Chamberlain AM, Chang AR, Cheng S, Das SR, Delling FN, Djousse L, Elkind MSV, Ferguson JF, Fornage M, Jordan LC, Khan SS, Kissela BM, Knutson KL, Kwan TW, Lackland DT, Lewis TT, Lichtman JH, Longenecker CT, Loop MS, Lutsey PL, Martin SS, Matsushita K, Moran AE, Mussolino ME, O'Flaherty M, Pandey A, Perak AM, Rosamond WD, Roth GA, Sampson UKA, Satou GM, Schroeder EB, Shah SH, Spartano NL, Stokes A, Tirschwell DL, Tsao CW, Turakhia MP, VanWagner LB, Wilkins JT, Wong SS, Virani SS, American Heart Association Council on E, Prevention Statistics C, and Stroke Statistics S. Heart Disease and Stroke Statistics-2019 Update: A Report From the American Heart Association. Circulation 139: e56-e528, 2019.

6. Betel D, Wilson M, Gabow A, Marks DS, and Sander C. The microRNA.org resource: targets and expression. Nucleic Acids Research 36: D149-D153, 2008.

7. Bostrom K, Watson KE, Horn S, Wortham C, Herman IM, and Demer LL. Bone morphogenetic protein expression in human atherosclerotic lesions. J Clin Invest 91: 1800-1809, 1993.

8. Bostrom KI, Rajamannan NM, and Towler DA. The regulation of valvular and vascular sclerosis by osteogenic morphogens. Circ Res 109: 564-577, 2011.

9. Bostrom KI, Yao J, Guihard PJ, Blazquez-Medela AM, and Yao Y. Endothelial-mesenchymal transition in atherosclerotic lesion calcification. Atherosclerosis 253: 124-127, 2016.

10. Cheng SL, Shao JS, Charlton-Kachigian N, Loewy AP, and Towler DA. MSX2 promotes osteogenesis and suppresses adipogenic differentiation of multipotent mesenchymal progenitors. J Biol Chem 278: 45969-45977, 2003.

11. Clarke MC, Talib S, Figg NL, and Bennett MR. Vascular smooth muscle cell apoptosis induces interleukin-1-directed inflammation: effects of hyperlipidemiamediated inhibition of phagocytosis. Circ Res 106: 363-372, 2010.

12. Corbett AH. Post-transcriptional regulation of gene expression and human disease. Curr Opin Cell Biol 52: 96-104, 2018. 
13. den Ruijter HM, Haitjema S, Asselbergs FW, and Pasterkamp G. Sex matters to the heart: A special issue dedicated to the impact of sex related differences of cardiovascular diseases. Atherosclerosis 241: 205-207, 2015.

14. Derwall M, Malhotra R, Lai CS, Beppu Y, Aikawa E, Seehra JS, Zapol WM, Bloch KD, and Yu PB. Inhibition of bone morphogenetic protein signaling reduces vascular calcification and atherosclerosis. Arterioscler Thromb Vasc Biol 32: 613-622, 2012.

15. Fotinos A, Fritz DT, Lisica S, Liu Y, and Rogers MB. Competing Repressive Factors Control Bone Morphogenetic Protein 2 (BMP2) in Mesenchymal Cells. J Cell Biochem 117: 439-447, 2016.

16. Garcia de Vinuesa A, Abdelilah-Seyfried S, Knaus P, Zwijsen A, and Bailly S. BMP signaling in vascular biology and dysfunction. Cytokine Growth Factor Rev 27: 65-79, 2016.

17. Gomez-Stallons MV, Wirrig-Schwendeman EE, Hassel KR, Conway SJ, and Yutzey KE. Bone Morphogenetic Protein Signaling Is Required for Aortic Valve Calcification. Arterioscler Thromb Vasc Biol 36: 1398-1405, 2016.

18. Hou X, Tang Z, Liu H, Wang N, Ju H, and Li K. Discovery of MicroRNAs associated with myogenesis by deep sequencing of serial developmental skeletal muscles in pigs. PLoS One 7: e52123, 2012.

19. Hu MC, Shi M, Zhang J, Quinones H, Griffith C, Kuro-o M, and Moe OW. Klotho deficiency causes vascular calcification in chronic kidney disease. J Am Soc Nephrol 22: 124-136, 2011.

20. Ichikawa S, Imel EA, Kreiter ML, Yu X, Mackenzie DS, Sorenson AH, Goetz R, Mohammadi M, White KE, and Econs MJ. A homozygous missense mutation in human KLOTHO causes severe tumoral calcinosis. J Clin Invest 117: 2684-2691, 2007.

21. Johnson JL. Elucidating the contributory role of microRNA to cardiovascular diseases (a review). Vascul Pharmacol 114: 31-48, 2019.

22. Karwowski W, Naumnik B, Szczepanski M, and Mysliwiec M. The mechanism of vascular calcification - a systematic review. Med Sci Monit 18: RA1-11, 2012.

23. Koh N, Fujimori T, Nishiguchi S, Tamori A, Shiomi S, Nakatani T, Sugimura K, Kishimoto T, Kinoshita S, Kuroki T, and Nabeshima Y. Severely reduced production of klotho in human chronic renal failure kidney. Biochem Biophys Res Commun 280: 1015-1020, 2001.

24. Kuro-o M, Matsumura Y, Aizawa H, Kawaguchi H, Suga T, Utsugi T, Ohyama Y, Kurabayashi M, Kaname T, Kume E, Iwasaki H, lida A, Shiraki-lida T, Nishikawa S, Nagai R, and Nabeshima YI. Mutation of the mouse klotho gene leads to a syndrome resembling ageing. Nature 390: 45-51, 1997.

25. Leopold JA. Cellular mechanisms of aortic valve calcification. Circ Cardiovasc Interv 5: 605-614, 2012. 
26. Li L, Miano JM, Mercer B, and Olson EN. Expression of the SM22alpha promoter in transgenic mice provides evidence for distinct transcriptional regulatory programs in vascular and visceral smooth muscle cells. J Cell Biol 132: 849-859, 1996.

27. Lovren F, Pan Y, Quan A, Singh KK, Shukla PC, Gupta N, Steer BM, Ingram AJ, Gupta M, Al-Omran M, Teoh H, Marsden PA, and Verma S. MicroRNA-145 targeted therapy reduces atherosclerosis. Circulation 126: S81-90, 2012.

28. Malhotra R, Burke MF, Martyn T, Shakartzi HR, Thayer TE, O'Rourke C, Li P, Derwall M, Spagnolli E, Kolodziej SA, Hoeft K, Mayeur C, Jiramongkolchai P, Kumar R, Buys ES, Yu PB, Bloch KD, and Bloch DB. Inhibition of bone morphogenetic protein signal transduction prevents the medial vascular calcification associated with matrix Gla protein deficiency. PLoS One 10: e0117098, 2015.

29. Miller JD, Weiss RM, and Heistad DD. Calcific aortic valve stenosis: methods, models, and mechanisms. Circ Res 108: 1392-1412, 2011.

30. Miller JD, Weiss RM, Serrano KM, Castaneda LE, Brooks RM, Zimmerman $\mathrm{K}$, and Heistad DD. Evidence for active regulation of pro-osteogenic signaling in advanced aortic valve disease. Arterioscler Thromb Vasc Biol 30: 2482-2486, 2010.

31. Moessler H, Mericskay M, Li Z, Nagl S, Paulin D, and Small JV. The SM 22 promoter directs tissue-specific expression in arterial but not in venous or visceral smooth muscle cells in transgenic mice. Development 122: 2415-2425, 1996.

32. Mohler ER, 3rd, Gannon F, Reynolds C, Zimmerman R, Keane MG, and Kaplan FS. Bone formation and inflammation in cardiac valves. Circulation 103: 15221528, 2001.

33. Nagy E, Eriksson P, Yousry M, CaidahI K, Ingelsson E, Hansson GK, Franco-Cereceda A, and Back M. Valvular osteoclasts in calcification and aortic valve stenosis severity. Int J Cardiol 168: 2264-2271, 2013.

34. Nakagawa Y, Ikeda K, Akakabe Y, Koide M, Uraoka M, Yutaka KT, KurimotoNakano R, Takahashi T, Matoba S, Yamada H, Okigaki M, and Matsubara H.

Paracrine osteogenic signals via bone morphogenetic protein-2 accelerate the atherosclerotic intimal calcification in vivo. Arterioscler Thromb Vasc Biol 30: 19081915, 2010.

35. Neven E, and D'Haese PC. Vascular calcification in chronic renal failure: what have we learned from animal studies? Circ Res 108: 249-264, 2011.

36. Nigam V, and Srivastava D. Notch1 represses osteogenic pathways in aortic valve cells. J Mol Cell Cardiol 47: 828-834, 2009.

37. Osman L, Yacoub MH, Latif N, Amrani M, and Chester AH. Role of human valve interstitial cells in valve calcification and their response to atorvastatin. Circulation 114: I547-552, 2006.

38. Paraskevopoulou MD, Georgakilas G, Kostoulas N, Vlachos IS, Vergoulis T, Reczko M, Filippidis C, Dalamagas T, and Hatzigeorgiou AG. DIANA-microT web server v5.0: service integration into miRNA functional analysis workflows. Nucleic Acids Res 41: W169-173, 2013. 
39. Rogers MB, Shah TA, and Shaikh NN. Turning Bone Morphogenetic Protein 2 (BMP2) on and off in Mesenchymal Cells. J Cell Biochem 116: 2127-2138, 2015.

40. Samavarchi-Tehrani P, Golipour A, David L, Sung HK, Beyer TA, Datti A, Woltjen K, Nagy A, and Wrana JL. Functional genomics reveals a BMP-driven mesenchymal-to-epithelial transition in the initiation of somatic cell reprogramming. Cell Stem Cell 7: 64-77, 2010.

41. Sanchez-Duffhues G, Garcia de Vinuesa A, van de Pol V, Geerts ME, de Vries MR, Janson SG, van Dam H, Lindeman JH, Goumans MJ, and Ten Dijke P. Inflammation induces endothelial-to-mesenchymal transition and promotes vascular calcification through downregulation of BMPR2. J Pathol 247: 333-346, 2019.

42. Shah TA, and Rogers MB. Unanswered Questions Regarding Sex and BMP/TGF-beta Signaling. Journal of Developmental Biology 6: 2018.

43. Shah TA, Zhu Y, Shaikh NN, Harris MA, Harris SE, and Rogers MB. Characterization of new bone morphogenetic protein (Bmp)-2 regulatory alleles. Genesis 55: 2017.

44. Shoshan E, Mobley AK, Braeuer RR, Kamiya T, Huang L, Vasquez ME, Salameh A, Lee HJ, Kim SJ, Ivan C, Velazquez-Torres G, Nip KM, Zhu K, Brooks D, Jones SJ, Birol I, Mosqueda M, Wen YY, Eterovic AK, Sood AK, Hwu P, Gershenwald JE, Robertson AG, Calin GA, Markel G, Fidler IJ, and Bar-Eli M. Reduced adenosine-to-inosine miR-455-5p editing promotes melanoma growth and metastasis. Nat Cell Biol 17: 311-321, 2015.

45. Taibi F, Metzinger-Le Meuth V, M'Baya-Moutoula E, Djelouat M, Louvet L, Bugnicourt JM, Poirot S, Bengrine A, Chillon JM, Massy ZA, and Metzinger L. Possible involvement of microRNAs in vascular damage in experimental chronic kidney disease. Biochim Biophys Acta 1842: 88-98, 2014.

46. Towler DA. Commonalities Between Vasculature and Bone An Osseocentric View of Arteriosclerosis. Circulation 135: 320-322, 2017.

47. Vacante F, Denby L, Sluimer JC, and Baker AH. The function of miR-143, miR-145 and the MiR-143 host gene in cardiovascular development and disease. Vascul Pharmacol 112: 24-30, 2019.

48. Weber M, Baker MB, Patel RS, Quyyumi AA, Bao G, and Searles CD. MicroRNA Expression Profile in CAD Patients and the Impact of ACEI/ARB. Cardiol Res Pract 2011: 532915, 2011.

49. Wirrig EE, Hinton RB, and Yutzey KE. Differential expression of cartilage and bone-related proteins in pediatric and adult diseased aortic valves. J Mol Cell Cardiol 50: 561-569, 2011.

50. Yamada S, and Giachelli CM. Vascular calcification in CKD-MBD: Roles for phosphate, FGF23, and Klotho. Bone 100: 87-93, 2017.

51. Yang X, Meng X, Su X, Mauchley DC, Ao L, Cleveland JC, Jr., and Fullerton DA. Bone morphogenic protein 2 induces Runx2 and osteopontin expression in human 
aortic valve interstitial cells: role of Smad1 and extracellular signal-regulated kinase 1/2. $J$ Thorac Cardiovasc Surg 138: 1008-1015, 2009.

52. Yang YJ, Luo S, and Wang LS. Effects of microRNA-378 on epithelialmesenchymal transition, migration, invasion and prognosis in gastric carcinoma by targeting BMP2. Eur Rev Med Pharmacol Sci 23: 5176-5186, 2019.

53. Yu Z, Seya K, Daitoku K, Motomura S, Fukuda I, and Furukawa K. Tumor necrosis factor-alpha accelerates the calcification of human aortic valve interstitial cells obtained from patients with calcific aortic valve stenosis via the BMP2-DIx5 pathway. $J$ Pharmacol Exp Ther 337: 16-23, 2011.

\section{Yutzey KE, Demer LL, Body SC, Huggins GS, Towler DA, Giachelli CM,} Hofmann-Bowman MA, Mortlock DP, Rogers MB, Sadeghi MM, and Aikawa E. Calcific aortic valve disease: a consensus summary from the Alliance of Investigators on Calcific Aortic Valve Disease. Arterioscler Thromb Vasc Biol 34: 2387-2393, 2014.

55. Zheng Y, Li T, Ren R, Shi D, and Wang S. Revealing editing and SNPs of microRNAs in colon tissues by analyzing high-throughput sequencing profiles of small RNAs. BMC Genomics 15 Suppl 9: S11, 2014. 
Fig. 1. BMP signaling and calcification levels in aorta from homozygous Klotho mutant mice. Aortas were isolated from control (Ctrl) mice with normal kidney function $\left(K^{+++}\right.$and $\left.K^{k / /+}\right)$ or mice homozygous $\left(K^{k / / k l}\right)$ for the Klotho mutation with renal disease (KK). Average parameter values are presented with standard error measurements (SEM). A. BMP signaling levels were assessed using an antibody that detects the phosphorylated forms of SMADs 1, 5, and 9 (pSMAD). Representative western blot panels showing pSMAD1/5/9 and total SMAD1/5/9 levels, males (left) and females (right). All female samples were loaded on one gel; however, one mis-loaded lane was excised from the image. B. pSMAD1/5/9 levels were normalized to total SMAD1/5/9 (tSMAD). Solid and hollow circles represent individual male and female values, respectively. C. Average calcium levels normalized to protein levels. D, E. Male littermates were scanned with an Albira PET/CT Imaging System (Carestream, Rochester, NY) set at $45 \mathrm{kV}, 400 \mu \mathrm{A}$, and $<35 \mu \mathrm{m}$ voxel size. Voxel intensities in the reconstructed images were evaluated and segmented with VivoQuant image analysis software (version 1.23, inviCRO LLC, Boston MA). The dashed white lines mark mineralized areas of the aortic sinus and ascending aorta present in the heart $(\mathbf{H t})$ of the Klotho mutant homozygote (E), but not in the heterozygous control $K \mathrm{~K}^{\mathrm{kl} / \mathrm{+}}(\mathrm{D})$. All images are shown at the same scale. Selected RNAs were measured by RT PCR and normalized to actin RNA levels. Bmp2 (F) and Smad1 (G) RNA levels did not change. Smad5 (H) and 9 (I) RNA levels were significantly increased relative to control mice. In all panels, the bars indicate the mean value $+/$ - SEM. ${ }^{*} p<0.05,{ }^{* *} p<0.01,{ }^{* * * *} p<$ 0.001 . Values did not differ significantly between sexes. All experiments were repeated at least twice with similar results.

Fig. 2. MicroRNA profiles in the aorta from control and Klotho homozygous (KK) mutant mice. RNA was extracted from the aorta of healthy controls $\left(K l^{+++}\right.$and $\left.K l^{k l+}\right)$ or Klotho homozygous $\left(K l^{k / k l}\right)$ mice $(K K)$. Samples were assayed using Affymetrix miRNA version 4.0. Data analysis was performed after Robust Multi-Array Average (RMA) normalization with Partek Genomics Suite 7.0. A, B. Volcano plots illustrate miRNAs whose abundances differed significantly in aorta from diseased mice compared to control mice $(p<0.05)$. The $X$ axis indicates $\log _{2}$ fold change and the $Y$ axis indicates $\log _{10} p$ value. Vertical dotted lines indicate 2 -fold change. C. The Venn diagram shows the number and percentage of miRNAs differentially expressed in male or female mice or in both sexes from a total of 1908 miRNAs.

Fig. 3. MiR-145 and miR-378a abundances are reduced in the aorta of Klotho homozygous mutant mice. Relative miRNA levels in healthy controls $\left(\mathrm{Kl}^{+/+}\right.$and $\left.\mathrm{K}^{\mathrm{kl/+}}\right)$ or Klotho homozygous $\left(\left.K\right|^{k / k l}\right)$ mice (KK) were assessed by RT PCR normalized against the corresponding U6 expression (A-D). The bars represent the mean value $+/$ - SEM and solid and hollow circles represent individual male and female values, respectively. ${ }^{*}=p<0.05,{ }^{* *}=p<0.01,{ }^{* * *}=p<0.005$. The abundances of miR-145-5p and $-3 p$ and miR-378a-5p did not differ significantly in males and females. However, miR-378a$3 p$ levels differed significantly in control mice $(p<0.00001)$, but not in Klotho homozygotes. 
Fig. 4. Vascular smooth muscle cell (VSMC)-specific lentivirus treatment increases mir-145 and mir-378a abundance in the aorta of Klotho mutant mice. A. Weaned Klotho mutant homozygous mice were treated with empty virus or virus bearing miR-145 or miR-378a pre-miRNAs. This lentiviral construct was previously shown to deliver miR-145 specifically to aortic VSMCs (27). The miR-145a-5p (B), miR-145a-3p (C) and miR-378a-5p (D), miR-378a-3p (E) abundances were evaluated by real-time PCR and normalized against the corresponding U6 abundance. The bars represent the mean value $+/$ - SEM. Solid and hollow circles represent individual male and female values, respectively. ${ }^{* *}=p<0.01,{ }^{* * *}=p<0.005,{ }^{* * *}=p<0.001$. The induction of miR-145a-5p and $-3 p$ and miR-378a-5p levels did not differ significantly between sexes and are presented as values normalized to U6 levels. However, as shown in Fig. 3, miR-378a-3p levels differed in control males and females. Consequently, miR-378a-3p levels are also presented normalized by sex to the values observed in mice exposed to empty virus $(\mathbf{F})$.

Fig. 5. Restoring MiR-145 levels reduces the abundance of RNAs encoding BMP signaling factors and aortic calcification. Increased mir-145 abundance in Klotho mutant mice significantly decreased Bmp2 (A) and Smad5 (C) RNA levels and calcium levels (E). Smad1 (B) and Smad9 (D) RNA levels did not change significantly. The bars represent the mean value $+/$ - SEM. Solid and hollow circles represent individual male and female values, respectively. ${ }^{*}=p<0.05,{ }^{* *}=p<0.01$.

Fig. 6. Restoring MiR-378a levels reduces the abundance of RNAs encoding BMP signaling factors and aortic calcification. Increased mir-378a abundance in Klotho mutant mice significantly decreased Bmp2 (A), Smad5 (B) RNA and calcium levels (C). The bars represent the mean value $+/$ - SEM. Solid and hollow circles represent individual male and female values, respectively. ${ }^{*}=p<0.05$. 
A. Male:

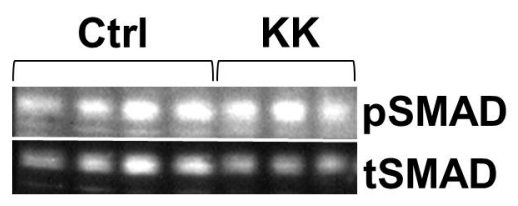

Female:

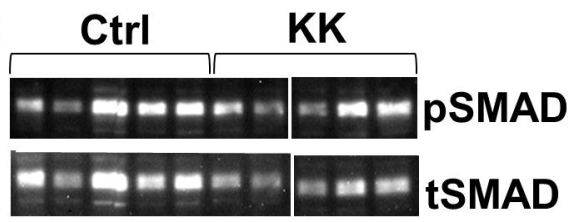

B.

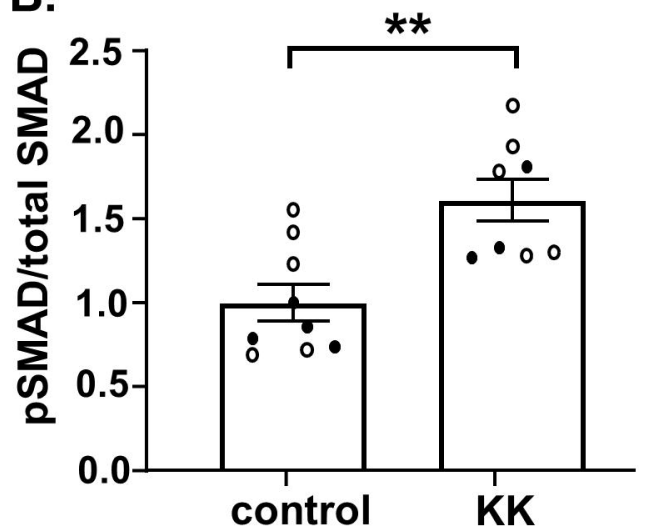

D. $\mathrm{KI}^{\mathrm{kl} /+}$ control heterozygote
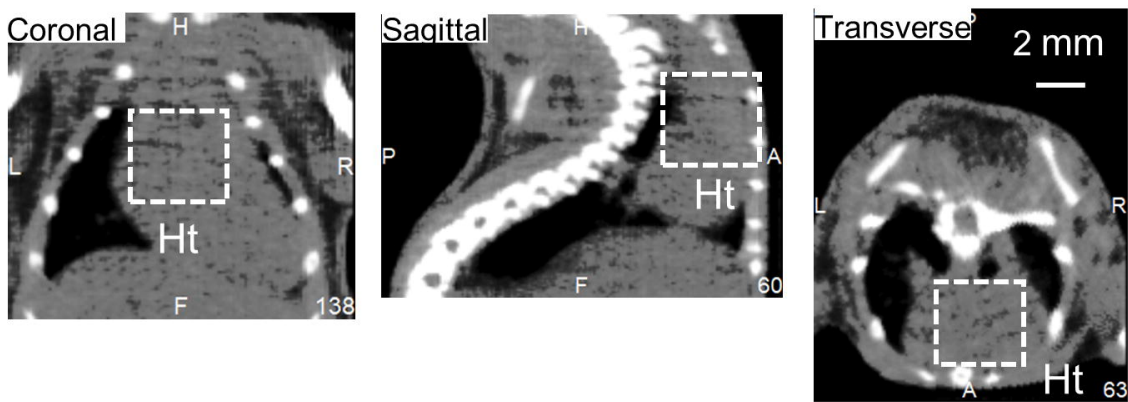

C.

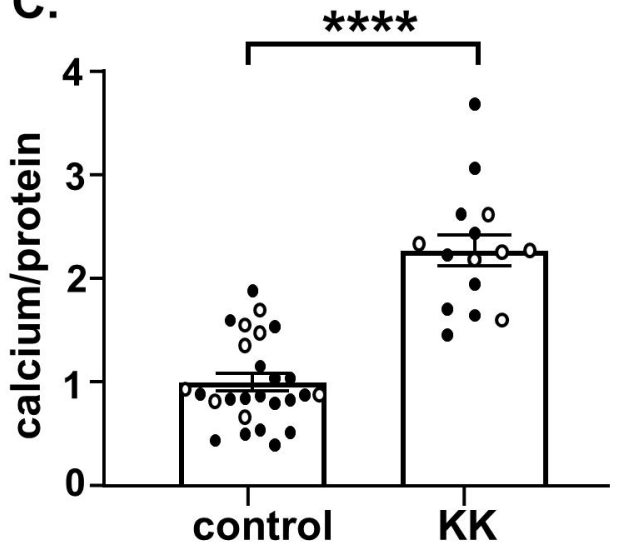

E. $\mathrm{KI}^{\mathrm{k} / \mathrm{kl}}$ mutant homozygote (KK)
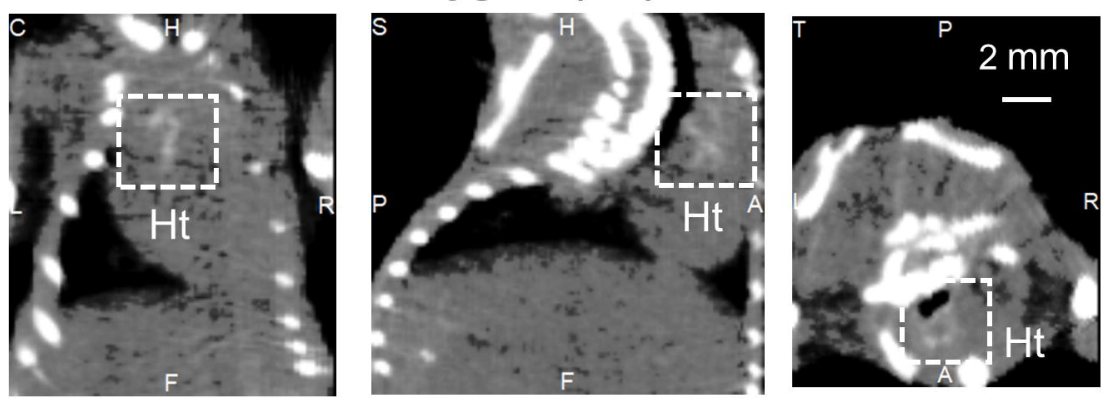

F.

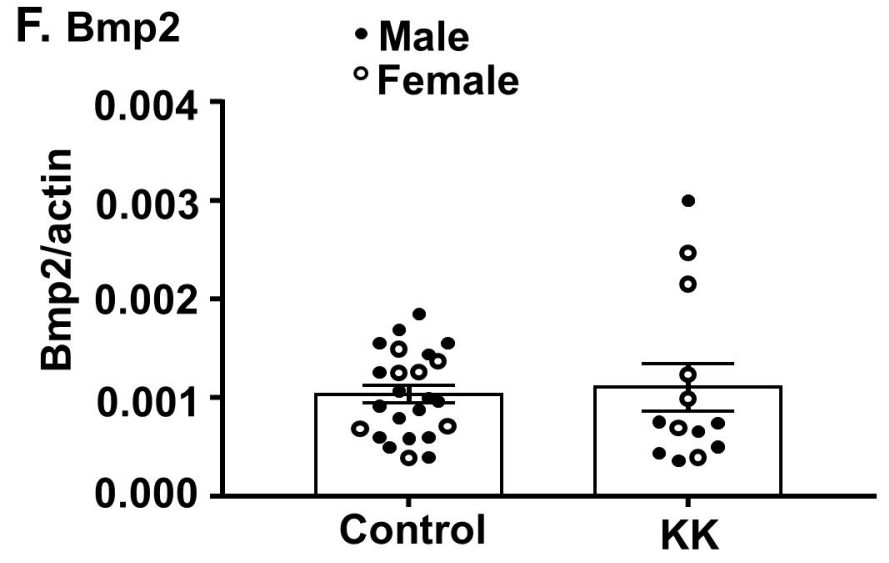

G. Smad1

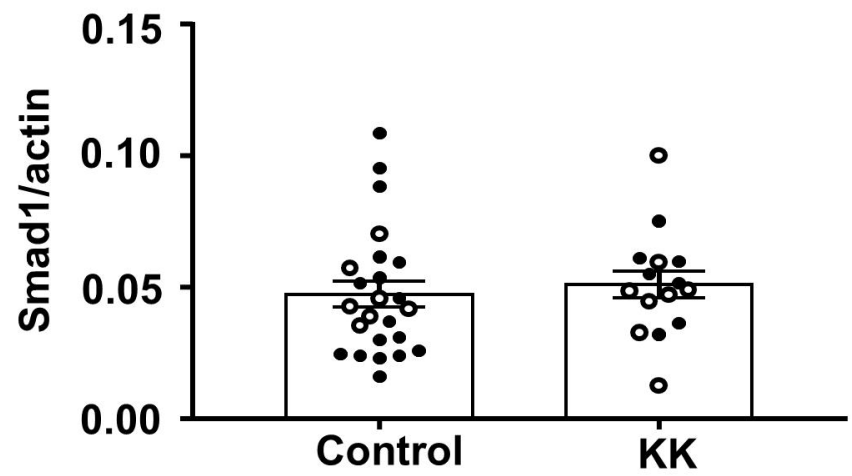

H. Smad5

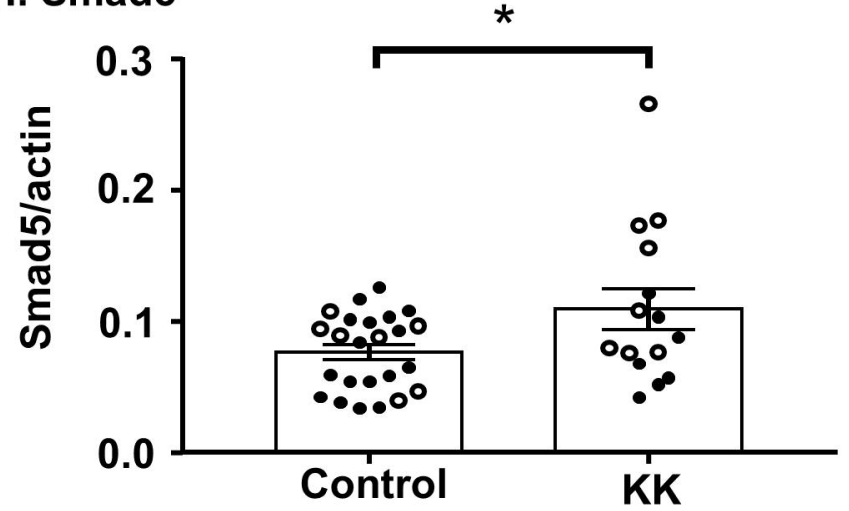

I. Smad9

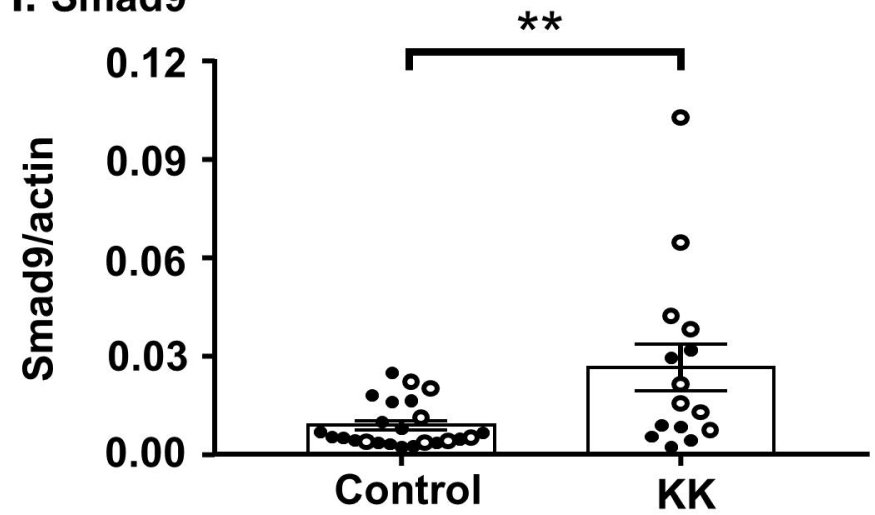


A.

certified bypeer review) is the author/funder. All rights reserved. No reuse allowed without permission. Male KK vs. Control

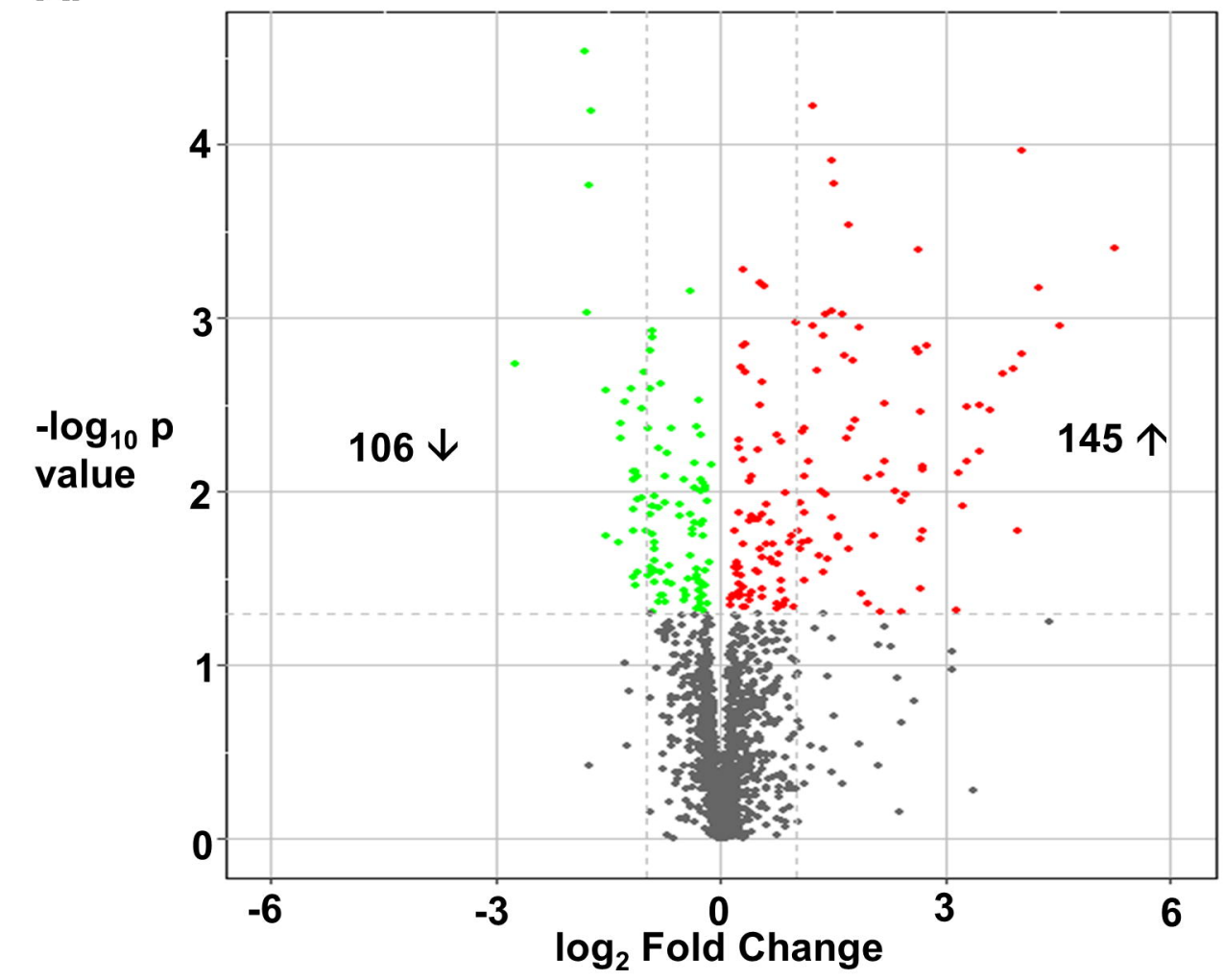

B.

Female KK vs. Control

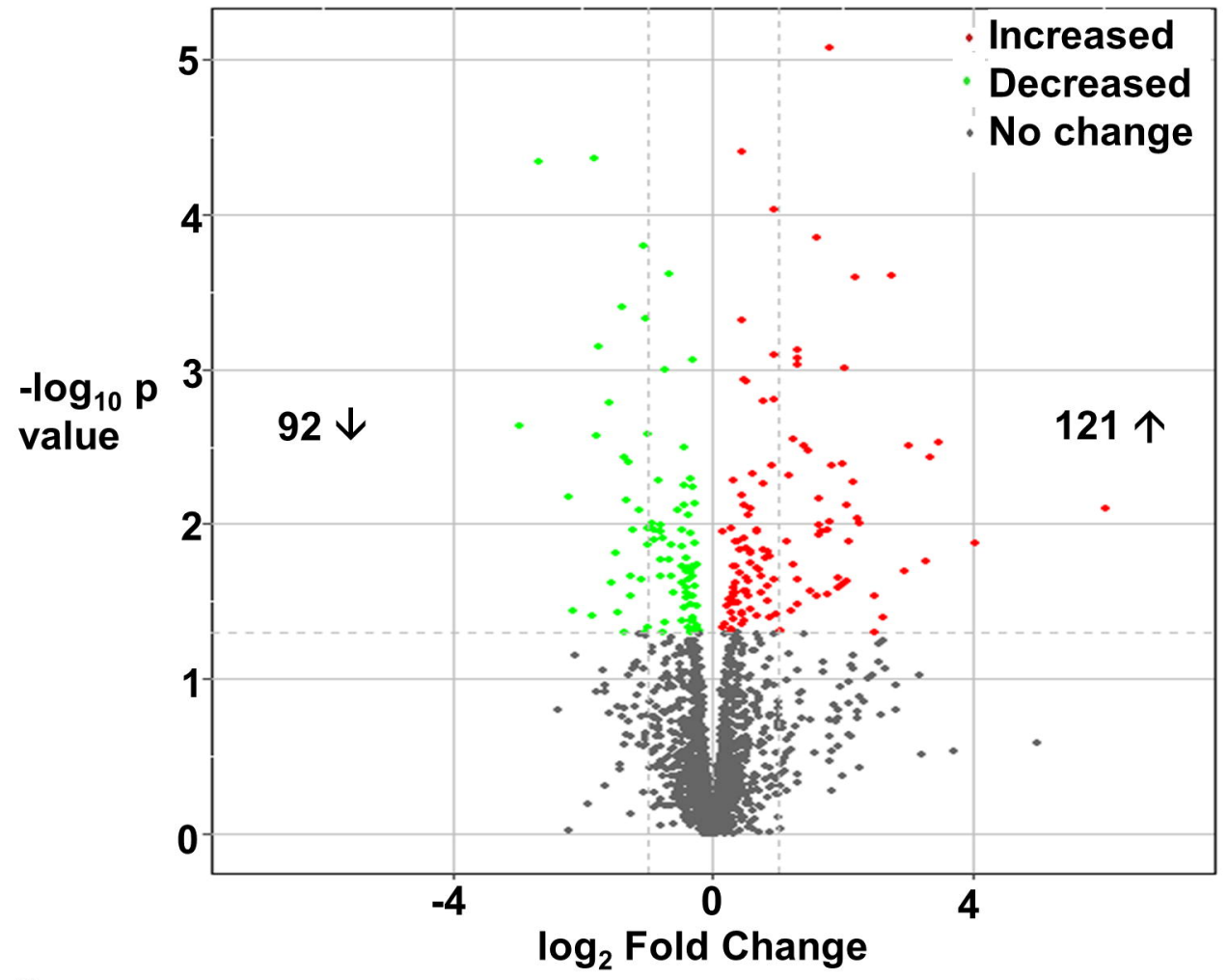

C.

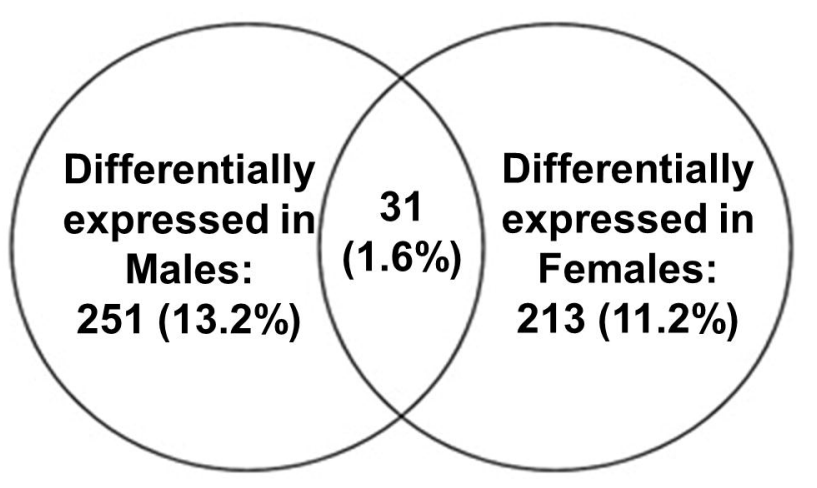


A. $m i R-145 a-5 p$

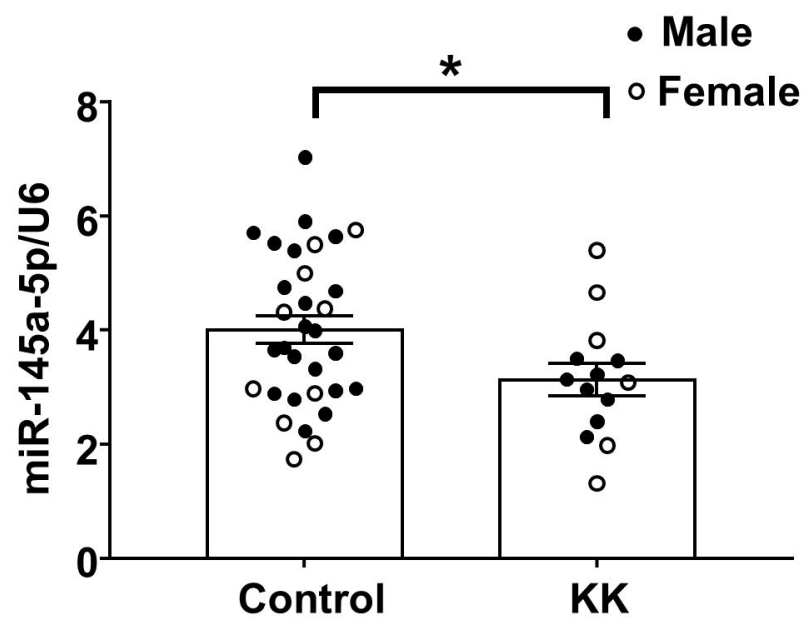

C. $m i R-378 a-5 p$

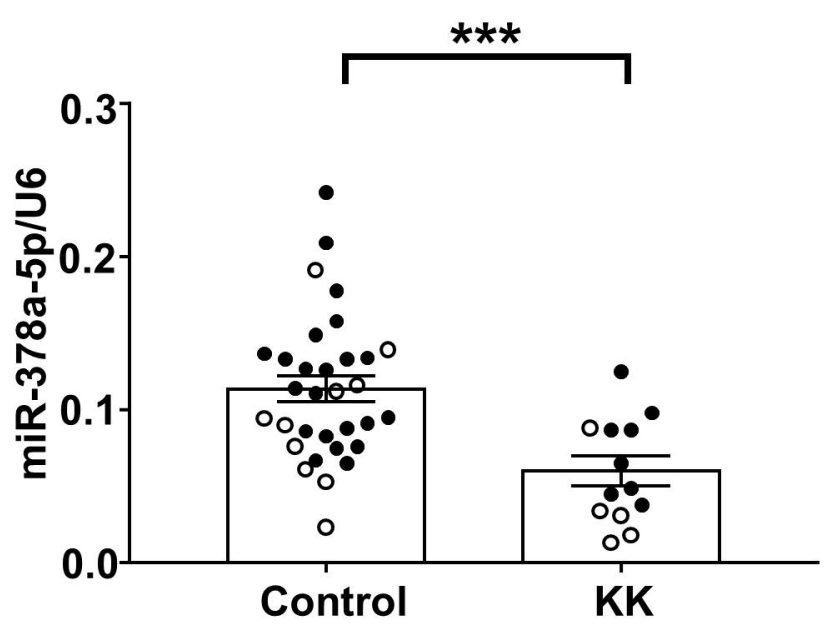

B. $m i R-145 a-3 p$

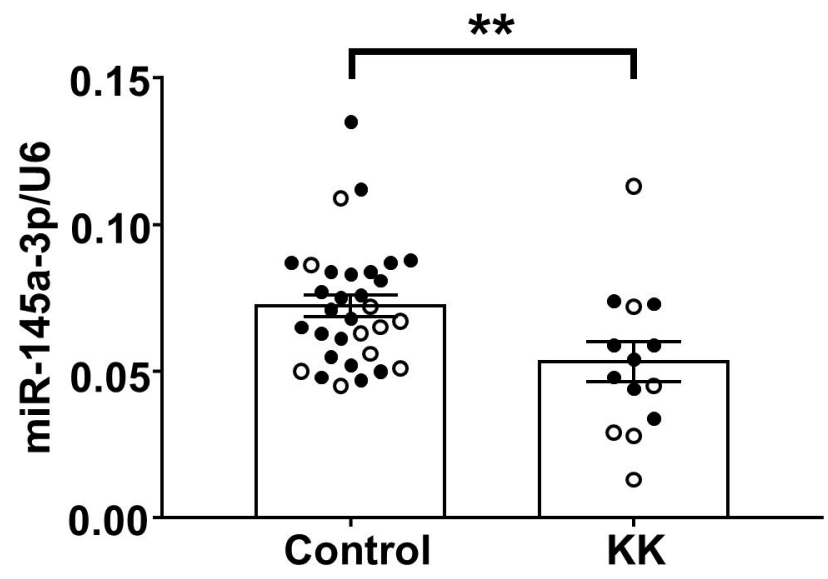

D. $m i R-378 a-3 p$

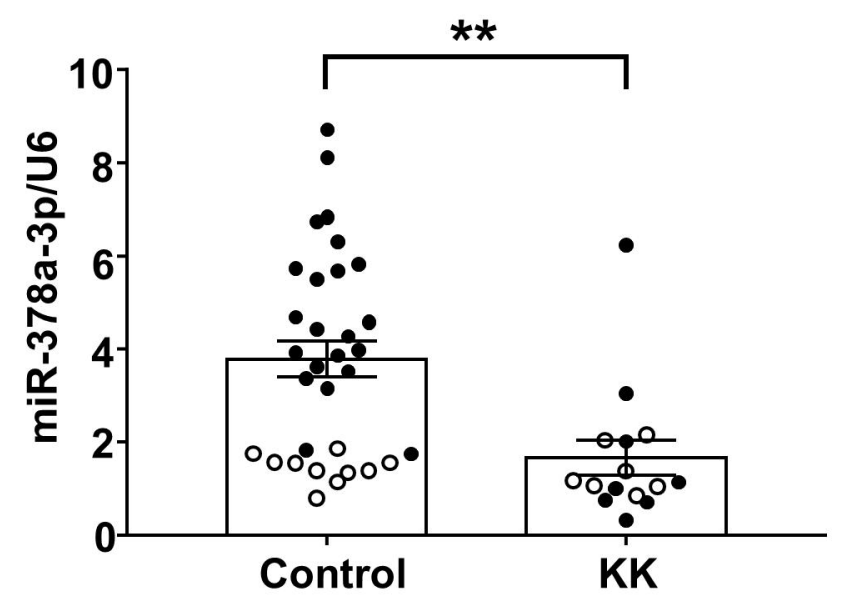


A.

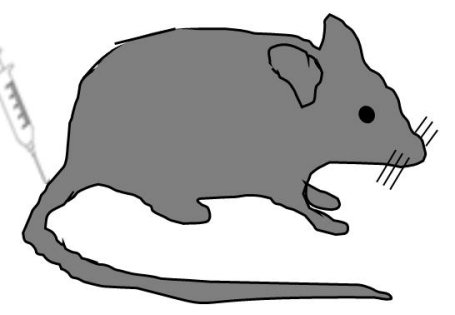

Virus injection

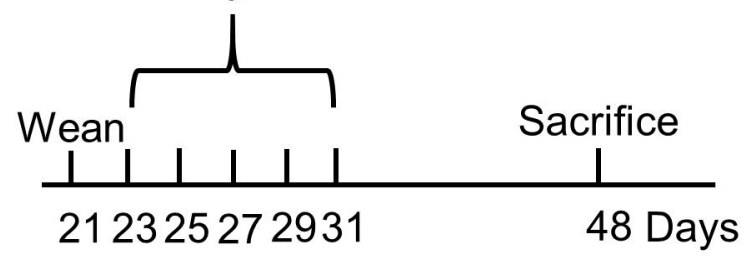

C. $\operatorname{miR}-145 a-3 p$

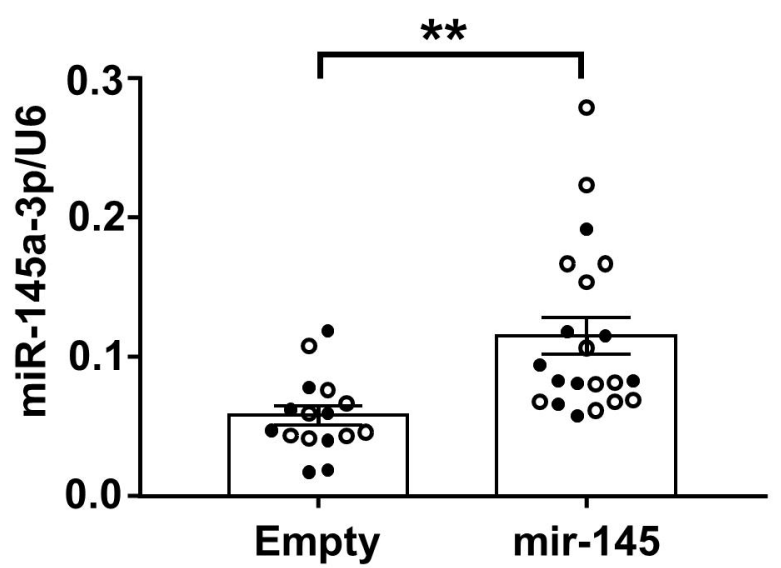

E. $m i R-378 a-3 p$

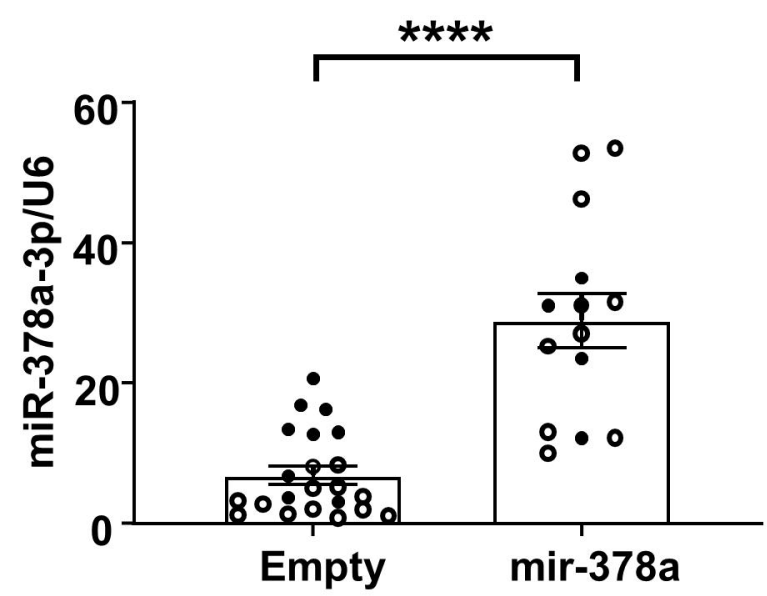

B. $m i R-145 a-5 p$

- Male

- Female

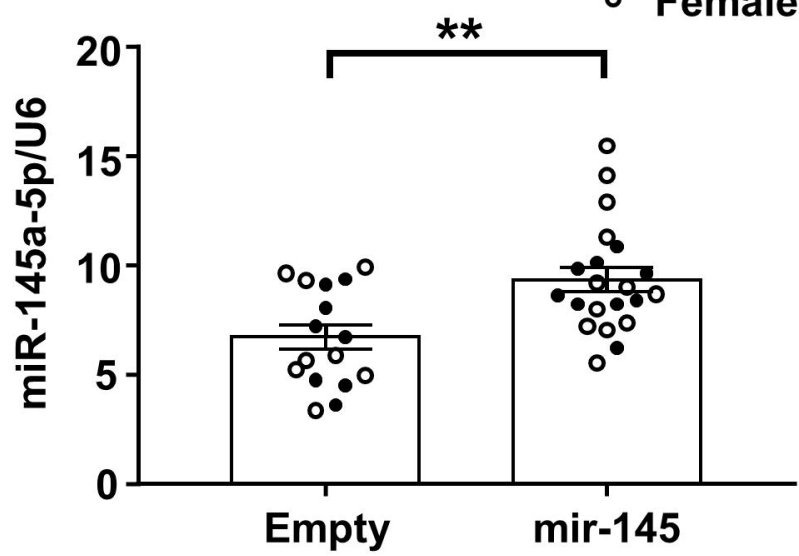

D. $m i R-378 a-5 p$

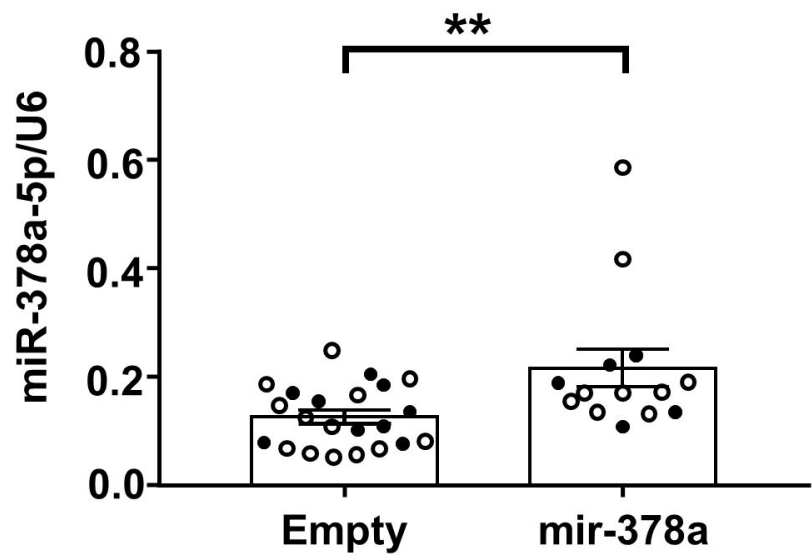

F. miR-378a-3p, normalized by sex

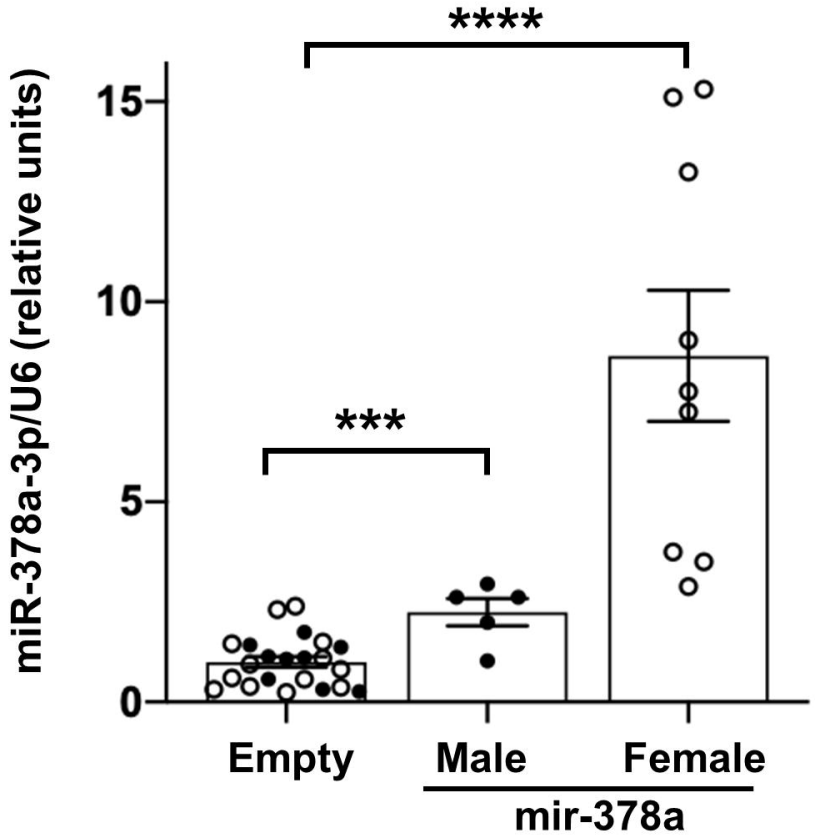



A. Bmp2
B. Smad1
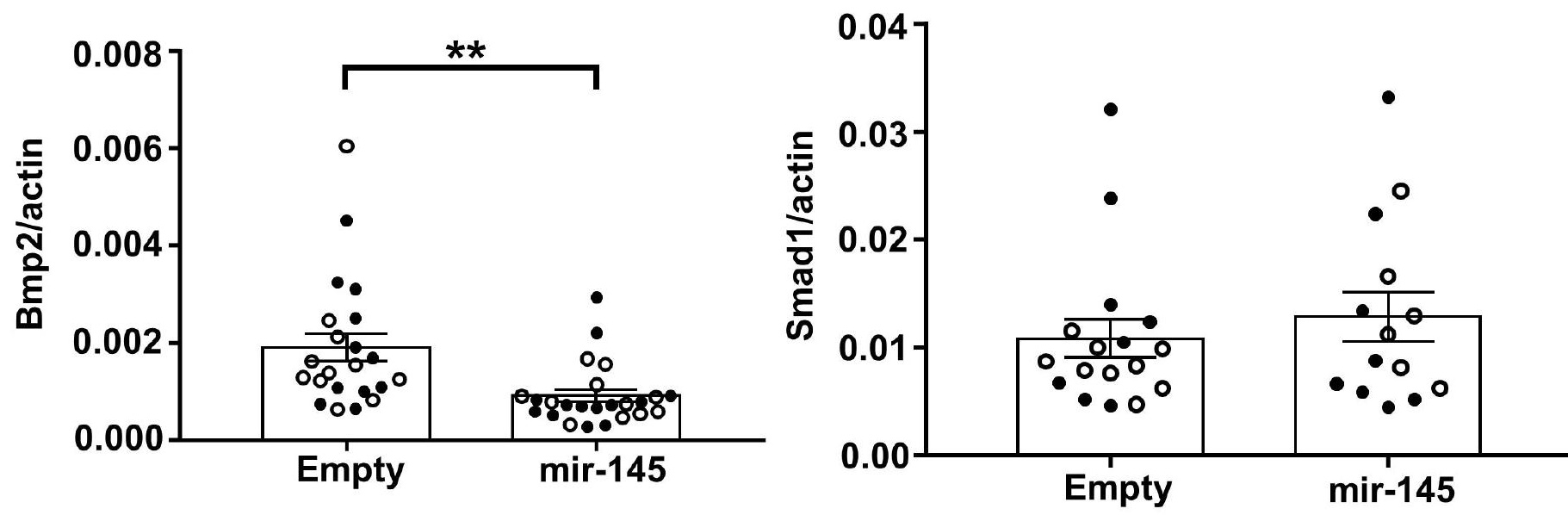

C. Smad5

D. Smad9
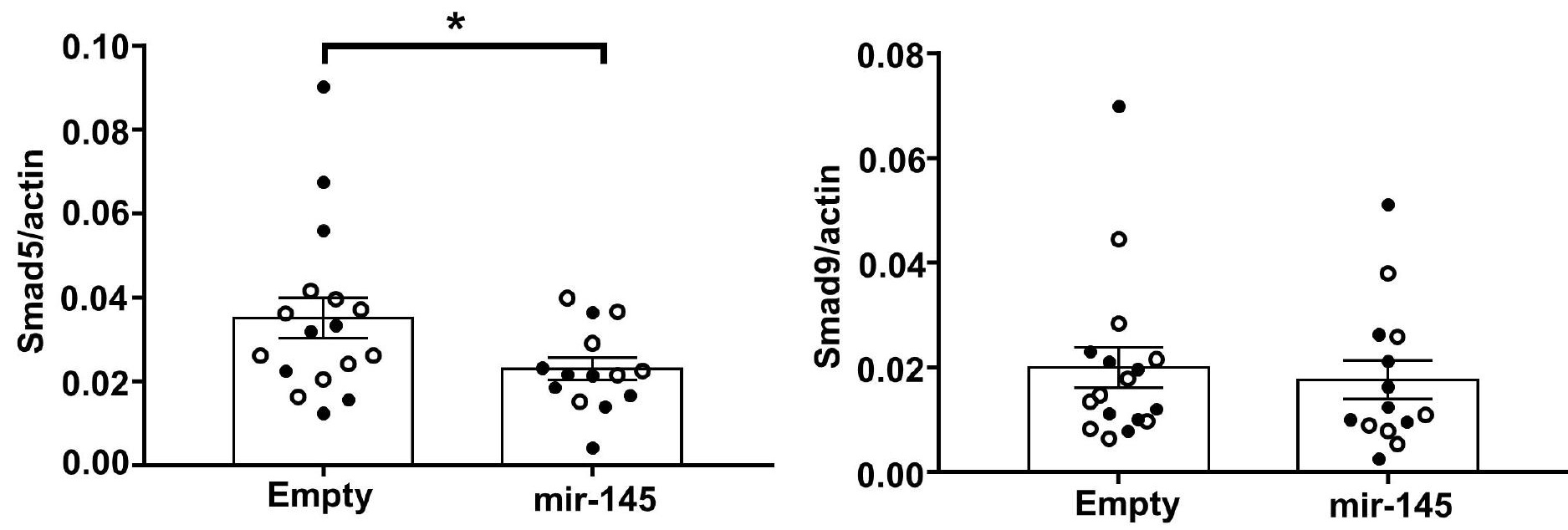

\section{E. Calcium}

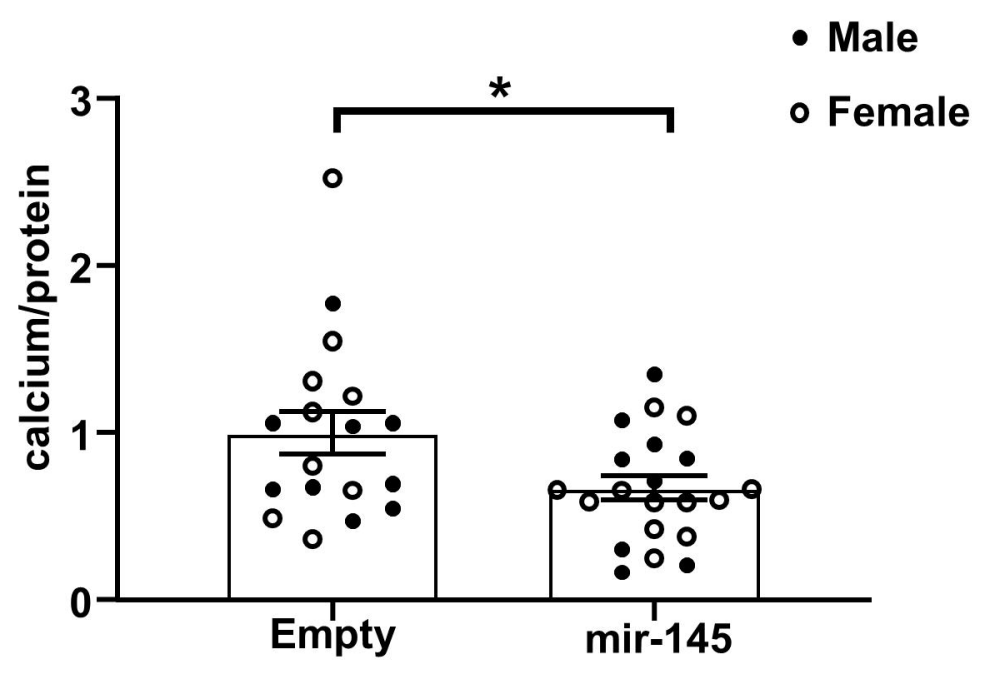


A. Bmp2

- Male

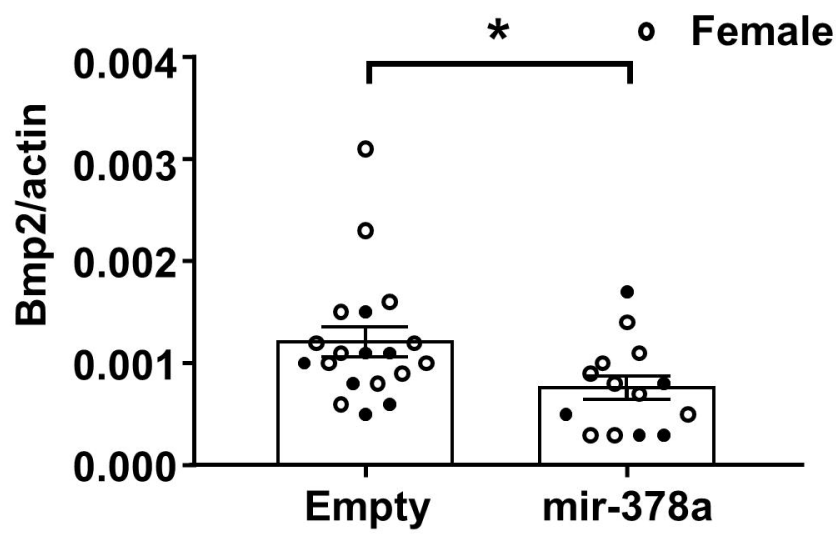

B. Smad5

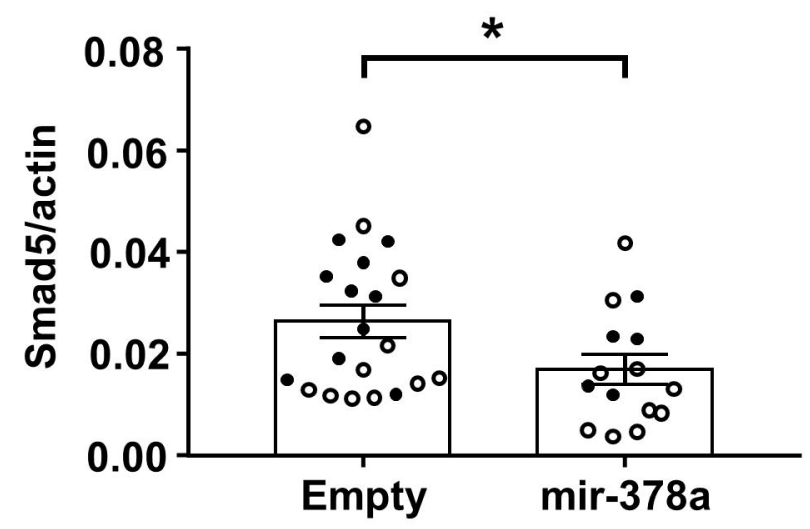

C. Calcium

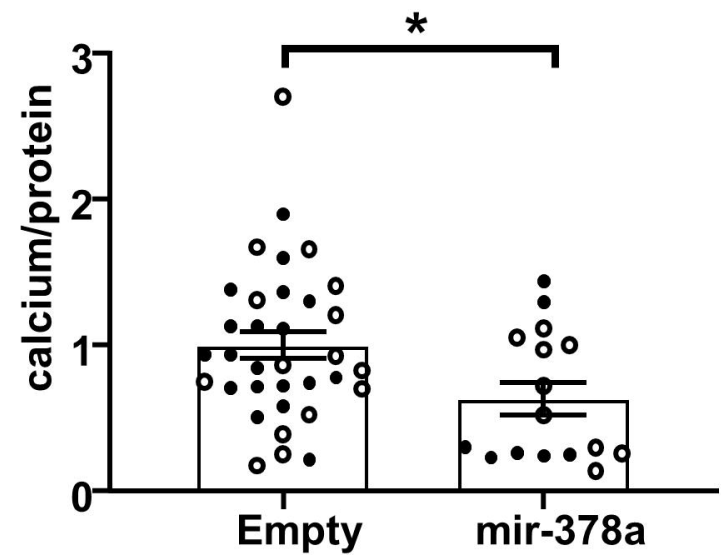




\section{MicroRNA Profiles in Calcified and Healthy Aorta Differ: Therapeutic Impact of miR-145 and miR-378}

Running title: miRNA replacement in aortic calcification

Ying Tang ${ }^{1, \dagger}$, Tapan A. Shah ${ }^{1, \dagger}{ }^{\dagger}$, Edward J. Yurkow ${ }^{2}$, and Melissa B. Rogers ${ }^{1, \neq}$

${ }^{1}$ Rutgers - New Jersey Medical School, Microbiology, Biochemistry, \& Molecular Genetics, Newark, NJ

${ }^{2}$ Rutgers University Molecular Imaging Center (RUMIC), Rutgers University, Piscataway, NJ

${ }^{\dagger}$ Co-first authors

¥Present Address: Advanced Cell Diagnostics, 7707 Gateway Blvd \#200, Newark, CA 94560

${ }^{\S}$ To whom should correspondence and reprint request be addressed to: Melissa B. Rogers, Ph.D., Microbiology, Biochemistry \& Molecular Genetics, Rutgers - NJ Medical School (NJMS), Center for Cell Signaling, Room F1216, 205 South Orange Ave., Newark, NJ 07103. Email: rogersmb@njms.rutgers.edu, telephone: 9739722984

Table 1. Number of mice ( $\mathrm{n}$ ) used for the miRNA profiling

Table 2. Reverse Transcription PCR primer sequences

Table 3. The number and percentage of miRNAs that differed in control relative to Klotho homozygotes (KK), $\mathrm{p}<0.05$

Table 4. Relative abundance of miRNAs that were differentially expressed in both male and female Klotho homozygous mutant mice as assessed by microarray comparisons.

Table 5. Genes targeted by selected miRNAs that may influence aortic calcification.

Table 6. Sequence alignments between miR-145a-5p, miR-145a-3p, miR-378a-5p and miR-378a-3p and mRNAs encoding BMP signaling proteins 
Table 1. Number of mice ( $n$ ) used for the miRNA profiling

\begin{tabular}{|c|c|c|}
\hline & Males & Females \\
\hline Group & $\mathbf{n}$ & $\mathbf{n}$ \\
\hline Control (Wt) & 5 & 4 \\
\hline Control (K+) & 2 & 1 \\
\hline $\begin{array}{c}\text { Klotho mutant } \\
(\mathrm{KK})\end{array}$ & 5 & 2 \\
\hline
\end{tabular}




\section{Table 2. Reverse Transcription PCR primer sequences}

\begin{tabular}{|l|l|}
\hline Name & Primer Sequence (5'-3') \\
\hline mmu-miR-145a-3p & F: GCGATTCCTGGAAATACTGTTCTTG \\
\hline mmu-miR-145a-5p & F: GTCCAGTTTTCCCAGGAATCCCT \\
\hline mmu-miR-378a-5p & F: CTCCTGACTCCAGGTCCTGTGT \\
\hline mmu-miR-378a-3p & F: ACTGGACTTGGAGTCAGAAGG \\
\hline Mouse Bmp2 & F: TAGATCTGTACCGCAGGCA \\
\hline Mouse Smad1 & R: GTTCCTCCACGGCTTCTTC \\
\hline Mouse Smad5 & F: GTGTATGAACTCACCAAAATGTGC \\
& R: TAACATCCTGCCGGTGGTATTC \\
\hline Mouse Smad9 & F: AACTTTCACCATGGCTTCCA \\
& R: CCAGAAGCTGAGCAAACTCC \\
\hline Mouse $\beta$-actin & F: CGATCATTCCATGAAGCTGACAA \\
& R: TGGGCAAGCCAAACCGATA \\
\hline
\end{tabular}


Table 3. The number and percentage of miRNAs that differed in control relative to Klotho homozygotes (KK), $\mathrm{p}<0.05$

\begin{tabular}{|l|l|l|}
\hline \multicolumn{2}{|l|}{ Male } & Female \\
\hline Any significant change & $145(7.6 \%)$ & $121(6.3 \%)$ \\
\hline Increased in KK & $106(5.6 \%)$ & $92(4.8 \%)$ \\
\hline Reduced in KK & $97(5.1 \%)$ & $71(3.7 \%)$ \\
\hline 1.5-fold difference & $60(3.1 \%)$ & $50(2.6 \%)$ \\
\hline Increased in KK & \multicolumn{2}{l|}{} \\
\hline Reduced in KK & $77(4.0 \%)$ & $48(2.5 \%)$ \\
\hline 2-fold difference & $25(1.3 \%)$ & $28(1.5 \%)$ \\
\hline Increased in KK &
\end{tabular}


Table 4. Relative abundance of miRNAs that were differentially expressed in both male and female Klotho homozygous mutant mice as assessed by microarray comparisons.

\begin{tabular}{|c|c|c|}
\hline Name & $\begin{array}{l}\% \text { control in males ( } p \\
\text { value) }\end{array}$ & $\begin{array}{l}\% \text { control in females (p } \\
\text { value) }\end{array}$ \\
\hline miR-669k-5p & $624(0.0004)$ & $395(0.02)$ \\
\hline miR-744-5p & $232(0.0001)$ & $304(0.0001)$ \\
\hline miR-1930-3p & $210(0.02)$ & $448(0.005)$ \\
\hline miR-7684-3p & $202(0.001)$ & $238(0.003)$ \\
\hline miR-383-5p & $153(0.02)$ & $176(0.02)$ \\
\hline miR-221-3p & $144(0.003)$ & $148(0.02)$ \\
\hline miR-6929-3p & $142(0.01)$ & $170(0.01)$ \\
\hline miR-7080-3p & $133(0.04)$ & $146(0.03)$ \\
\hline miR-468-3p & $126(0.047)$ & $190(0.0008)$ \\
\hline miR-7240-3p & $110(0.045)$ & $115(0.04)$ \\
\hline miR-3069-3p & $190(0.02)$ & $49(0.049)$ \\
\hline miR-7019-5p & $146(0.02)$ & $57(0.02)$ \\
\hline miR-7685-3p & $122(0.0005)$ & $82(0.007)$ \\
\hline miR-679-5p & $122(0.002)$ & $82(0.02)$ \\
\hline$m i R-370-5 p$ & $117(0.03)$ & $81(0.04)$ \\
\hline miR-7665-3p & $85(0.04)$ & $124(0.04)$ \\
\hline miR-466m-3p & $84(0.02)$ & $124(0.03)$ \\
\hline miR-17-5p & $76(0.02)$ & $194(0.002)$ \\
\hline miR-181c-3p & $45(0.03)$ & $320(0.01)$ \\
\hline miR-335-3p & $84(0.04)$ & $72(0.02)$ \\
\hline$m i R-100-5 p$ & $75(0.0007)$ & $62(0.0003)$ \\
\hline miR-30c-2-3p & $64(0.004)$ & $54(0.01)$ \\
\hline$m i R-139-3 p$ & $62(0.03)$ & $42(0.03)$ \\
\hline miR-330-3p & $56(0.006)$ & $39(0.004)$ \\
\hline miR-193b-5p & $54(0.03)$ & $16(0.00005)$ \\
\hline miR-193b-3p & $54(0.001)$ & $28(0.00004)$ \\
\hline$m i R-187-5 p$ & $53(0.02)$ & $21(0.007)$ \\
\hline
\end{tabular}




\begin{tabular}{|l|l|l|}
\hline miR-30c-1-3p & $53(0.049)$ & $28(0.04)$ \\
\hline miR-378a-5p & $53(0.002)$ & $38(0.0004)$ \\
\hline miR-193a-3p & $49(0.003)$ & $30(0.0007)$ \\
\hline miR-182-5p & $44(0.003)$ & $50(0.046)$ \\
\hline
\end{tabular}


Table 5. Genes targeted by selected miRNAs that may influence aortic calcification. Twenty-five miRNAs were selected for increased scrutiny because they were differentially regulated to a significant extent in both male and female Klotho mutant homozygotes or affected calcium levels in the in vivo gain-of-function assay (Table 4, Table S2, GSE135759, Fig. 6 and 7). We list the known BMP signaling modulators (Table S3) or the master osteogenic regulators (MSX2, HGNC:7392 and RUNX2, HGNC:10472) that TargetScan predicted were targeted by each miRNA. Genes have been grouped into primarily activating or inhibiting functional categories. All but four of these differentially regulated miRNAs (miR-744-5p, miR-383-5p, miR7240-3p, miR-378a-3p) were predicted to target genes that modulate osteogenic differentiation.

\begin{tabular}{|c|c|c|}
\hline Name & activator & inhibitor \\
\hline $\operatorname{miR}-669 k-5 p$ & $\begin{array}{l}\text { BMPR1A, BMPR2, BMP7, } \\
\text { MSX2, RUNX2, SMAD5 }\end{array}$ & $\begin{array}{l}\text { FST, LTBP1, TWSG1, } \\
\text { SMURF1 }\end{array}$ \\
\hline \multicolumn{3}{|l|}{ miR-744-5p } \\
\hline miR-1930-3p & $\begin{array}{l}\text { ACVR2A, BMPR1A, BMPR2, } \\
\text { RUNX2 }\end{array}$ & BAMBI, NBL1, LTBP1 \\
\hline miR-7684-3p & $\begin{array}{c}\text { BMPR1A, BMPR2, MSX2, } \\
\text { RUNX2, SMAD5 }\end{array}$ & $\begin{array}{l}\text { FST, GREM2, SMAD7, } \\
\text { SMURF1, SMURF2 }\end{array}$ \\
\hline \multicolumn{3}{|l|}{ miR-383-5p } \\
\hline miR-221-3p & ACVR2B & \\
\hline $\operatorname{miR}-6929-3 p$ & BMPR2, MSX2, RUNX2, SMAD9 & $\begin{array}{c}\text { BAMBI, HRDL1, LTBP1, } \\
\text { SOSTDC1, TWSG1 }\end{array}$ \\
\hline $\operatorname{miR}-7080-3 p$ & $\begin{array}{l}\text { ACVRL1, BMPR1B, BMP7, } \\
\text { SMAD4 }\end{array}$ & $\begin{array}{l}\text { CHRDL, FSTL1, GREM2, NBL1, } \\
\text { LTBP1, LTBP2 }\end{array}$ \\
\hline $\operatorname{miR}-468-3 p$ & BMP2, BMPR2, SMAD4, SAMD5 & $\begin{array}{c}\text { CHRDL1, SOSTDC1, GREM2, } \\
\text { DAND5, BAMBI }\end{array}$ \\
\hline \multicolumn{3}{|l|}{ miR-7240-3p } \\
\hline miR-335-3p & $\begin{array}{c}\text { BMP7, ACVR2A, ACVR2B, } \\
\text { BMPER, BMPR1B, SMAD1, } \\
\text { SMAD4, SAMD5 }\end{array}$ & $\begin{array}{l}\text { BAMBI, DCN, CHRDL1, } \\
\text { GREM1,GREM2, LTBP2, } \\
\text { FSTL1, FSTL5, SOSTDC1, } \\
\text { TWSG1 }\end{array}$ \\
\hline miR-100-5p & BMPR2 & \\
\hline $\operatorname{miR}-30 c-2-3 p$ & $\begin{array}{l}\text { BMPR2, BMPR1A, BMPR1B, } \\
\text { ACVR2A, ACVR2B, SMAD4 }\end{array}$ & $\begin{array}{c}\text { SMAD7, SMURF1, DAND5, } \\
\text { FST, GREM1 }\end{array}$ \\
\hline $\operatorname{miR}-139-3 p$ & BMP7, ACVRL1, SMAD4 & $\begin{array}{c}\text { SMURF1, SMURF2, BAMBI, } \\
\text { GREM1 }\end{array}$ \\
\hline $\operatorname{miR}-330-3 p$ & $\begin{array}{c}\text { ACVR2B, BMPR1A, BMPR1B, } \\
\text { BMPR2, RUNX2 }\end{array}$ & $\begin{array}{c}\text { BAMBI, BMPER, SMAD7, } \\
\text { SOSTDC1, SMURF2 }\end{array}$ \\
\hline miR-193b-5p & $\begin{array}{l}\text { ACVR2B, BMPR1A, BMP2, } \\
\text { RUNX2, SMAD4, SMAD9 }\end{array}$ & $\begin{array}{l}\text { BMPER, GREM2, SOSTDC1, } \\
\text { SMURF1 }\end{array}$ \\
\hline miR-193b-3p & SMAD5, SMAD9 & GREM1 \\
\hline miR-187-5p & ACVR2B, BMPR1A, BMP2, & BAMBI, DAND5, NBL1, SMAD7 \\
\hline
\end{tabular}




\begin{tabular}{|c|c|c|}
\hline miR-30c-1-3p & $\begin{array}{c}\text { SMPR2, BMPR1A, BMPR1B, } \\
\text { ACVR2A, ACVR2B, SMAD4 }\end{array}$ & $\begin{array}{c}\text { SMAD7, SMURF1, DAND5, } \\
\text { FST, GREM1 }\end{array}$ \\
\hline miR-378a-5p & $\begin{array}{c}\text { ACVR2A, ACVR2B, BMPR1A, } \\
\text { BMPR1B, BMP2, SMAD5 }\end{array}$ & $\begin{array}{c}\text { BMPER, FST, GREM1, } \\
\text { GREM2, TWSG1, SMURF1, } \\
\text { SMURF2 }\end{array}$ \\
\hline miR-193a-3p & SMAD5, SMAD9 & SMAD7 \\
\hline miR-182-5p & ACVR1, SMAD1 & \\
\hline miR-145a-5p & ACVR2A, SMAD1, SMAD5, & SMAD9 \\
miR-145a-3p & $\begin{array}{c}\text { ACVRL1, ACVR2A, ACVR2B, } \\
\text { BMPR2, BMPR1A, BMPR1B, } \\
\text { BMP2, BMP7, RUNX2 }\end{array}$ & $\begin{array}{c}\text { BMPER, CHRDL1, FSTL1, } \\
\text { GREM1, GREM2, LTBP2, } \\
\text { SMAD7, SOSTDC1, SMURF1, } \\
\text { SMURF2 }\end{array}$ \\
\hline miR-378a-3p & \multicolumn{2}{|c}{} \\
\hline
\end{tabular}


Table 6. Sequence alignments between miR-145a-5p, miR-145a-3p, miR-378a-5p and miR-378a-3p and mRNAs encoding BMP signaling proteins

\begin{tabular}{|c|c|c|c|}
\hline \multicolumn{2}{|c|}{ Predicted mmu-miR-145a target sites } & \multirow{2}{*}{$\begin{array}{c}\text { Tools } \\
\text { Miranda }\end{array}$} & \multirow{2}{*}{$\begin{array}{c}\begin{array}{c}\text { Conservation } \\
\text { of site }\end{array} \\
\text { Within rodents }\end{array}$} \\
\hline $\begin{array}{r}\text { muBmp2 3' UTR } \\
\text { miR-145a-5p }\end{array}$ & $\begin{array}{l}737 \\
5^{\prime} \ldots \text { GGGAAUAAUUAGGAAAACUGUGAC. . . } \\
|||||||||||||||| \mid \\
3^{\prime} \quad \text { UCCCUAAGGACCCUUUUGAC-CUG }\end{array}$ & & \\
\hline $\begin{array}{r}\text { muBmp2 3' UTR } \\
\text { miR-145a-3p }\end{array}$ & $\begin{array}{c}580 \\
5 ' \ldots \text { AUAUUCUUCAAUUCUCAGGAAU. . . } \\
\qquad|||:||||||| \\
3^{\prime} \quad \text { GUUCUUGUCAUAAAGGUCCUUA }\end{array}$ & Miranda & $\begin{array}{l}\text { Between } \\
\text { rodents, } \\
\text { humans, and } \\
\text { chicken }\end{array}$ \\
\hline $\begin{array}{r}\text { muBmp2 3' UTR } \\
\text { miR-145a-3p }\end{array}$ & 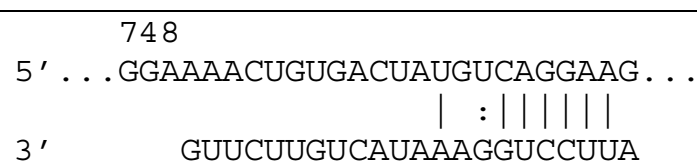 & Miranda & Within rodents \\
\hline $\begin{array}{r}\text { muSmad1 3' UTR } \\
\text { miR-145a-5p }\end{array}$ & 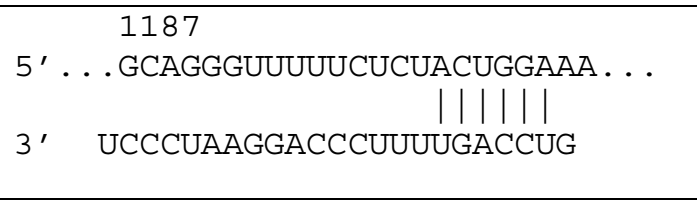 & Targetscan & $\begin{array}{l}\text { Between } \\
\text { rodents, } \\
\text { mammals, and } \\
\text { birds }\end{array}$ \\
\hline $\begin{array}{r}\text { muSmad5 3' UTR } \\
\text { miR-145a-5p }\end{array}$ & $\begin{array}{l}234 \\
5 \\
5^{\prime} \ldots \text { UUAGCAUUGAUCUUAAACUGGAA . . . } \\
3^{\prime} \quad \text { UCCCUAAGGACCCUUUUUGACCUG }\end{array}$ & Targetscan & $\begin{array}{l}\text { Between } \\
\text { mammals }\end{array}$ \\
\hline $\begin{array}{r}\text { muSmad9 3' UTR } \\
\text { miR-145a-5p }\end{array}$ & 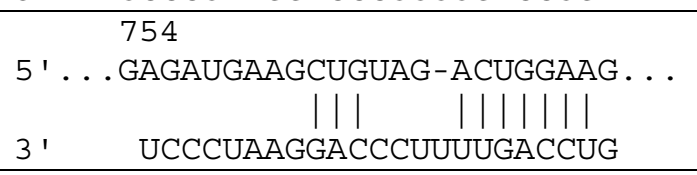 & Targetscan & Within rodents \\
\hline \multicolumn{4}{|c|}{ Predicted mmu-miR-378 target sites } \\
\hline $\begin{array}{r}\text { muBmp2 3' UTR } \\
\text { miR-378a-5p }\end{array}$ & $\begin{array}{l}579 \\
5 \\
5^{\prime} \ldots \text { UAUAUUCUUCAAUUCUCAGGAAU. . } \\
3^{\prime} \quad \text { UGUGUCCUGGACCUCAGUCCUC }\end{array}$ & $\begin{array}{c}\text { Miranda } \\
\text { Targetscan }\end{array}$ & $\begin{array}{c}\text { Between } \\
\text { rodents, } \\
\text { mammals, and } \\
\text { birds }\end{array}$ \\
\hline $\begin{array}{r}\text { muBmp2 3' UTR } \\
\text { miR-378a-5p }\end{array}$ & 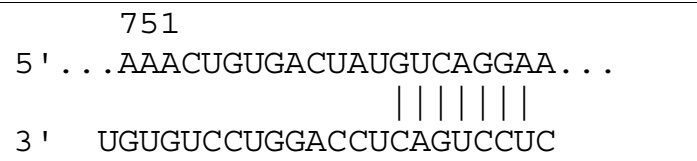 & $\begin{array}{c}\text { Miranda } \\
\text { Targetscan }\end{array}$ & Within rodents \\
\hline $\begin{array}{r}\text { muBmp2 3' UTR } \\
\text { miR-378a-3p }\end{array}$ & $\begin{array}{l}508 \\
51 \ldots \text { GUUCACAAGUUCAAGUCCAAA. . . } \\
\qquad 3^{\prime} \quad \text { GGAAGACUGAGGUUCAGGUCA }\end{array}$ & Miranda & $\begin{array}{l}\text { Between } \\
\text { rodents and } \\
\text { humans }\end{array}$ \\
\hline $\begin{array}{r}\text { muSmad5 3' UTR } \\
\text { miR-378a-5p }\end{array}$ & $\begin{array}{c}1156 \\
5 \\
5^{\prime} \ldots \text { UUUACUUGGCAGCCUUCAGGAAC . . . } \\
3^{\prime} \quad \text { UGUGUCCUGGACCUCAGUCCUC }\end{array}$ & Targetscan & Within rodents \\
\hline
\end{tabular}

